\title{
Medieval buildings and environmental change: chronology, ecology and political administration at Castle Sween, Knapdale
}

\author{
Mark Thacker ${ }^{1}$
}

Received: 6 March 2020 / Accepted: 15 July 2020 / Published online: 17 September 2020

(C) The Author(s) 2020

\begin{abstract}
This paper presents results from an integrated programme of landscape, buildings and materials analysis undertaken at Castle Sween under the aegis of the Scottish Medieval Castles \& Chapels C14 Project (SMCCCP). A suite of petrographic, archaeobotanical and radiocarbon analyses are employed to present the first independent dating evidence relating to the construction of three phases of the castle complex, including a primary phase curtain-walled enclosure widely regarded as mainland Scotland's earliest surviving medieval masonry castle. This data is generally consistent with previous interpretations of the building's stratigraphy and architectural style, although an earlier than expected determination for the northeast tower draws further attention the contrasting character of this particular structure. Archaeobotanical analysis of the largest assemblage of mortar-entrapped relict limekiln fuel fragments undertaken by the project, thus far, also hints at wider changes in the surrounding environment. Correlating this buildings evidence with palynological and other data associated with the political, vegetational and climate history of the surrounding lordship, and across Argyll more widely, is beginning to align the construction of Castle Sween with broader ecological processes from which the surrounding environment has emerged.
\end{abstract}

Keywords Castle $\cdot$ Climate $\cdot$ Environment $\cdot$ Medieval $\cdot$ Radiocarbon $\cdot$ Vegetation

\section{Introduction}

The curtain-walled enclosure at Castle Sween is widely regarded as the earliest surviving medieval masonry castle in mainland Scotland (Fig. 1). The initial construction of this building in the late twelfth to early thirteenth century, therefore, represents a moment of huge significance for the country's social and architectural history, whilst evidence for a further four masonry phases and occupation up to the midseventeenth century attests to the continued importance of the site throughout the medieval period and beyond.

Historical discourse surrounding the region within which Castle Sween is situated, however, has charted changes in the area's medieval political geography which have international reach; with this western fringe of mainland Scotland framed as

Electronic supplementary material The online version of this article (https://doi.org/10.1007/s12520-020-01162-7) contains supplementary material, which is available to authorized users.

Mark Thacker

mark.thacker@stir.ac.uk

1 University of Stirling, 27 Upper Carloway, Isle of Lewis, Scotland a battle ground between the competing interests of the Scottish, Norwegian and English Crowns in the eleventh to fourteenth centuries, mediated by powerful regional lordships which retained close political and cultural ties with nearby Ireland throughout (Brown 2004, 255). On an even wider scale, climate change across the northern hemisphere has also been recognized as an influential factor in the region's politics during this period, as conditions transitioned from the relatively benign and warm Medieval Climate Anomaly (MCA) which has often been ascribed to $800-1300 \mathrm{AD}$, to the much less predictable (and often economically disastrous) later medieval and early modern 'climatic worsening' or Little Ice Age (LIA) (Oram and Adderley 2008; Fagan 2000; Lamb 1977, 449). Indeed, the Scottish Crown's increased ability to exert political over-lordship during the prosperous latter end of the MCA has often been used to explain the apparently sudden emergence of masonry castle buildings throughout the west Highlands and Islands during the thirteenth century.

Relative precision is crucial for comparative multidisciplinary interpretation, however, and these often sweeping interpretations of the region's built environment currently lack geographical and chronological resolution. There is very little surviving contemporary documentary evidence relating to 


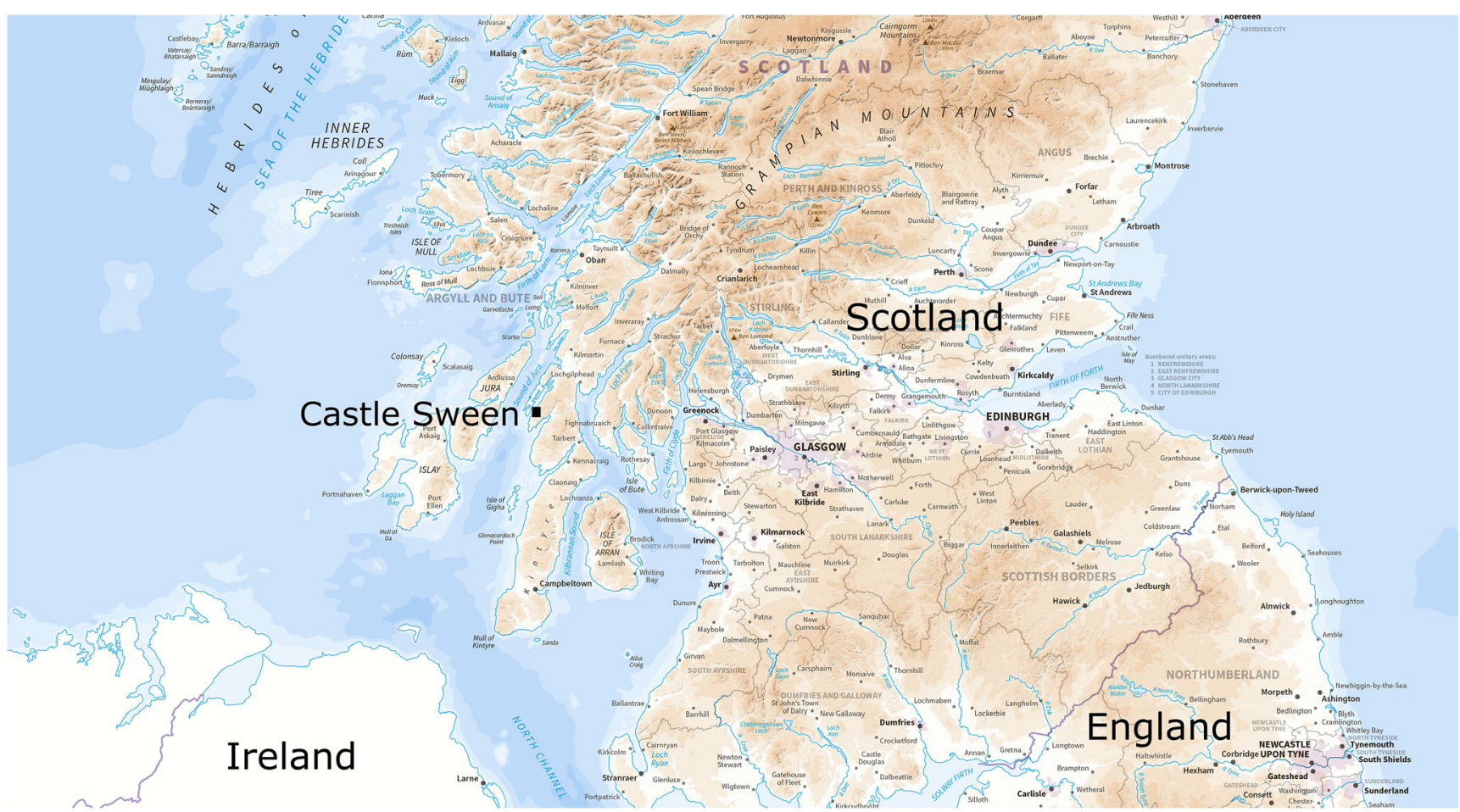

Fig. 1 West of Scotland location of Castle Sween (map contains OS data @ C Crown copyright and database right 2020)

western Scotland in the high medieval period and the evidence for later medieval climate change is predicated on regionspecific proxy sources which are widely dispersed throughout the northern hemisphere (Lamb 1977). Moreover, chronological evidence for the construction of many western Scottish castle buildings often relies on very broad architectural typologies which can span hundreds of years. Ultimately, evidence for a direct relationship between these wide-ranging historical-ecological processes and particular medieval sites is largely absent.

Recent work, however, has demonstrated that analysis of the masonry materials used to construct these buildings can provide a potent comparative focus for more holistic interpretations of the surrounding historic environment, particularly when such studies are informed by radiocarbon data from mortar-entrapped relict limekiln fuels (hereafter MERLF). A number of buildings within the southwest Highlands and Inner Hebridean islands of Scotland are currently being investigated in this way, although these do tend to be predominantly single-phase structures. Against this background, the complex of upstanding buildings surviving at Castle Sween presents a valuable opportunity to undertake a more chronologically broad multiphase study, within which we might expect any dramatic changes in the surrounding political and physical environment to have an impact on constructional resources, thereby lending those materials further palaeoecological potential.

To investigate that potential, Castle Sween has been subject to an integrated programme of landscape, buildings and materials analysis under the aegis of the Scottish Medieval Castles \& Chapels C14 Project (SMCCCP). This paper presents initial results of that study; including petrographic characterization of mortar samples from multiple structural phases, archaeobotanical characterization of the largest MERLF assemblage examined by the project thus far, and the first independent dating evidence relating to this internationally significant castle complex. Through that process, the study begins to integrate the building's constructional development within a finer-grained chronologically-constrained model of environmental change.

\section{Materials and methods}

The methodology follows previously presented protocols (Thacker 2020) and in this study is comprised of four main strands:

\section{Literature search of documented evidence and previous interpretations}

This has included charter, cartographic, and other historical evidence from the medieval and later periods; nineteenth century antiquarian and more recent survey descriptions and materials studies of the upstanding building; reported results from a late twentieth century excavation at the east end of the main castle enclosure; and various geological and 
palaeoenvironmental studies undertaken in the surrounding region.

\section{On-site characterization and sampling of exposed masonry materials from each phase}

The surface of the monument was closely examined from ground level and from a stepladder, to establish where direct phasing relationships between structures were evident. As part of this process, constructional and intrusive materials within each structural phase were examined and characterized in situ using a $\times 10$ hand lens, and representative mortar, MERLF, and stone samples removed for further lab-based analysis. Various walkover surveys of the surrounding environment have also been undertaken with the aim of identifying possible material sources.

\section{Lab-based microscopic and radiocarbon analysis of material samples}

Polished slide-mounted thick (1-2 $\mathrm{mm})$ sections were prepared from all mortar and stone samples, to enable analysis in reflected light. A single thick section from each mortar sample was then selected for re-mounting and polishing to a standard $(30 \mu \mathrm{m})$ thin section, to enable examination of the same surface in polarized light (Thacker 2016) with a separate thin section for each stone sample also prepared. Potential source material provenances were investigated using standard petrographic techniques, with mortar sample characterization predicated on identifying carbonate and carbonaceous potential limekiln relicts, and inorganic non-calcareous aggregate tempers (Elsen 2006). MERLF samples were fractured to expose a transverse section and examined in reflected light with reference to standard anatomical literature (Schweingruber 1990), to establish tree taxa to genus level (where possible). On the basis of taxonomy, morphology, distribution and phase, a sub-assemblage of MERLF samples was then selected for AMS radiocarbon analysis (Dunbar et al. 2016).

\section{The development of a chronological model for the construction of the castle complex}

Bayesian modelling techniques are employed within the OxCal programme (Bronk Ramsey 2009a) to generate preliminary date range estimates for the completion of each period of construction, initially using 'standalone' radiocarbon measurements and phasing information only (Thacker 2020). These chronological estimates are then used to situate the castle's constructional evidence within a wider environmental context.

\section{Results and interpretation}

\section{Previous evidence}

The first direct historical reference to Castle Sween relates to a John of Menteith charter, place-dated from 'Castrum Suffin' in 1353 and granting various lands in Knapdale to Campbell of Lochawe (Fraser 1880, II, no. 26). In the documentary evidence from this and subsequent periods, the castle and lordship of Knapdale are often closely related, with other undated (but probably broadly contemporary) Menteith charters to Archibald Campbell including the pennyland within which 'Castel Swine' was situated, and formally appointing him 'keeper' of the building (ibid.). The Menteiths held the castle of Skipness (in southern Knapdale) by 1262, and the inclusion of 'The land of the earl of Menteith of Knapdale' within the newly configured 1293 Sheriffdom of Lorn (University of St Andrews 2007-2020) suggests they had held formal title to the wider lordship for some time before the 1301 letters exchanged between John MacSween and King Edward I confirming their continued possession (cf. Brown 2004, 260; Bain 1884 no. 1255). Robert the Steward was in possession of Knapdale by 1366, however, and on accession to the throne issued a charter in 1376 granting the lordship to John MacDonald - Lord of the Isles (Maitland Thomson 1912, no 569; Munro and Munro 1986, xxvi, no. A10). This latter document does not mention the castle itself but, apart from a brief period in 1430 when control of Knapdale with custody of both Sween and Skipness castles was granted to two landowners from Ayrshire, the lords of the Isles appear to have held the building continuously through to late fifteenth century, with successive documents appointing the MacNeils as keepers on their behalf in 1440, 1455 and 1472 (Munro and Munro 1986, nos. 33, 60 and 102). Indeed, although the MacDonalds formally forfeit their extensive mainland Scottish territories (including Knapdale) in 1475, parliament accused their clan chief (another John) of giving 'treasonable assistance' to rebels holding Castle Sween in 1478, following reports that he was 'stuffing' the building with men, victuals and arms of war (ibid, lxxi). Thereafter, in 1481, the Campbell earls of Argyll were finally granted custody of the castle together with extensive lands in Knapdale, and the building appears to have remained in their control until its midlate seventeenth century abandonment and subsequent ruination (RCAHMS 1992, 259).

The medieval lordship of Knapdale included three parishes and extended from Loch Crinan and Loch Gilp at its northern boundary with Glassary, to the Claonaig Water at its southern boundary with Kintyre (Innes 1854, 37 n.12; Dunbar and Duncan 1971, 5-7; Fig. 2). Various post-medieval maps clearly identify the location of Castle Sween, on the south-eastern shore of a long SW-NE oriented fjord of the same name, which cuts deeply into the north-west coast of the Knapdale peninsula (Figs. 2 and 3a). Somewhat unusually, the name 'Swyn' is inscribed at this location on a hydrographic chart reportedly 


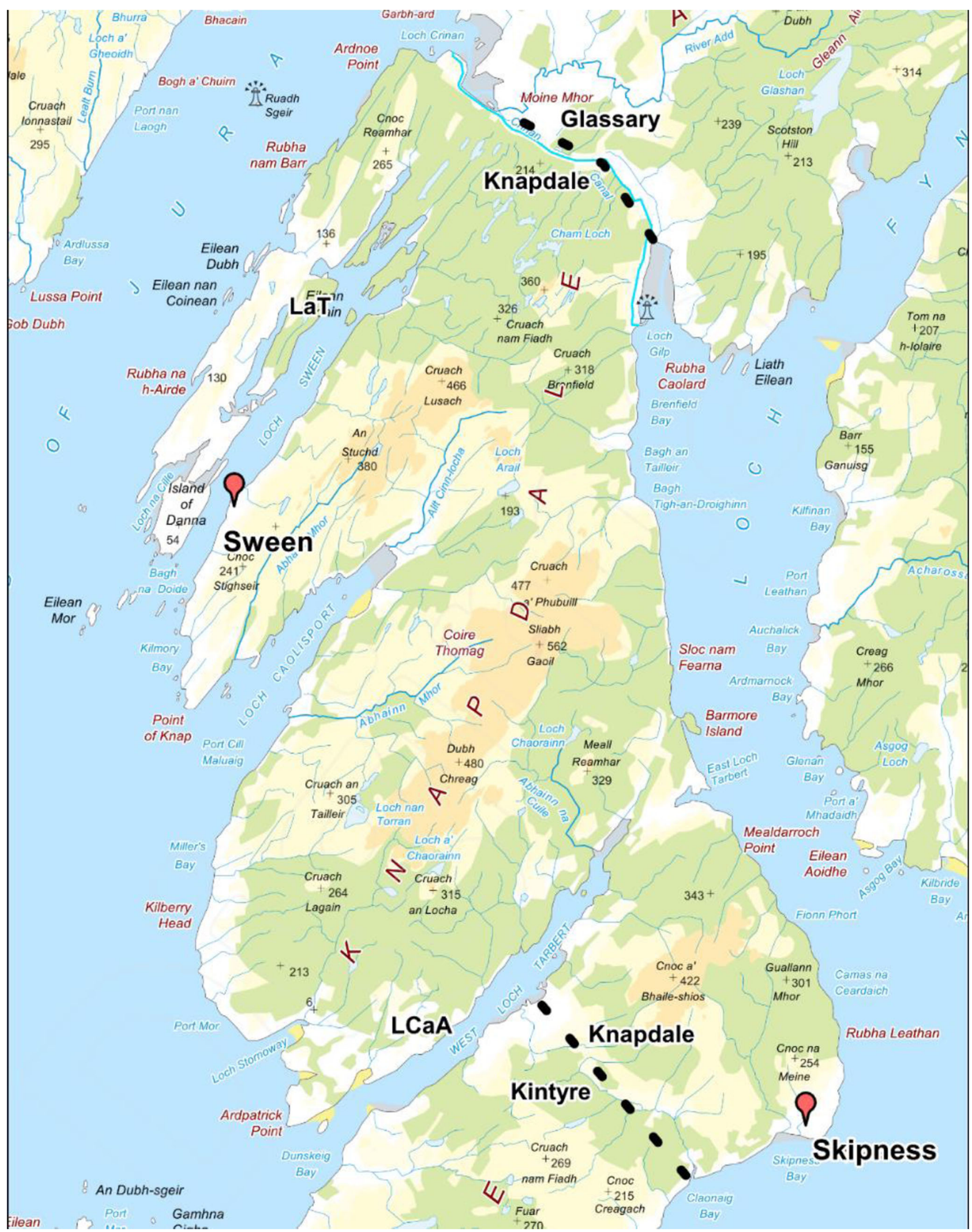

Fig. 2 Location of Castle Sween within the lordship of Knapdale (Contains OS data $\odot$ Crown copyright and database right 2020) 

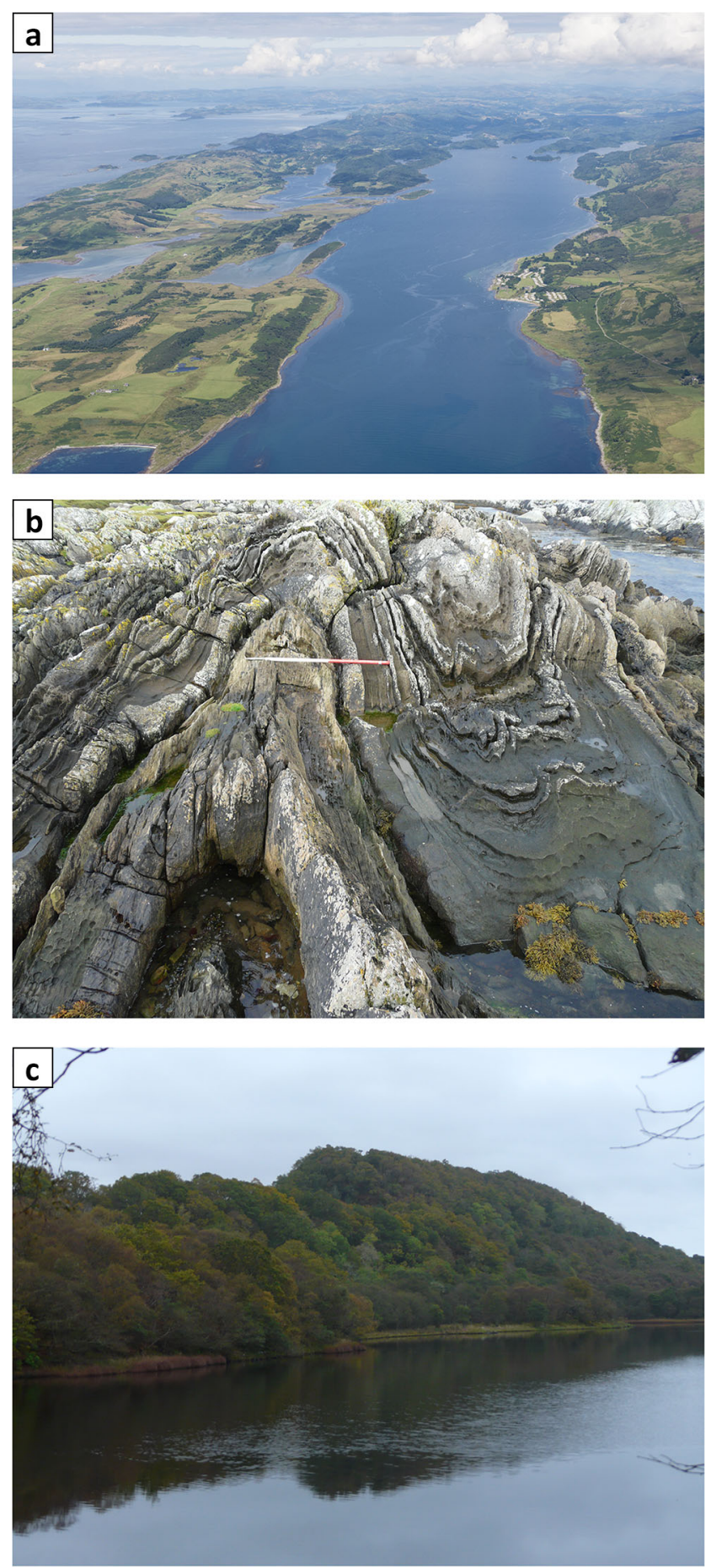

Fig. 3 a-c The Loch Sween Environment. a Aerial photograph looking up Loch Sween from the southwest. Highlighting various ecological zones, including extensive semi-natural woodland at the loch head and low-lying agricultural land on the north-west shore (including the island of Danna in the foreground). Castle Sween (now surrounded by caravans) is located on the opposite on the SE shore, close to the water's edge, at the narrowest part of the loch. Image not included in Creative Commons licence; DP239044 (C) Historic Environment Scotland. b Oak woodland at the head of Loch Sween. Highlighting that this (ecologically) internationally important woodland grows right down to the water's edge. No scale. $\mathbf{c}$ Metamorphic geology exposed on the shore at Kilmory Bay, close to the mouth of Loch Sween. Highlighting the dramatic folding and slaty cleavage of the Ardnoe Group which includes fine-grained quartzites, limestone and slates. Scale $500 \mathrm{~mm}$ drafted during James V's early sixteenth century voyage around Scotland; published in Paris in 1583 and reproduced by John Adair (1703). Thereafter, 'Swyn Ca.' and 'Swin Ca.' are identified on two of Gerhard Mercator's (1595) maps of Scotland together with a generic single-towered symbol, whilst 'Castel Svyn' and 'Loch Castel Swyn' are also identified on Blaeu $(1654 a, b)$ maps of the Province of Knapdale and Isle of Jura. Curiously, the site is not acknowledged in Pont's description of Knapdale, within which Tarbert is the only castle mentioned (Pont 1583-1614, 84), but both 'Castle Swine' and 'Loch Swin' are identified on General Roy's (1747-1755) Military Survey of Scotland map, which also included a blocked-out plan drawing of the building. The first reasonably accurate depiction of the surviving castle building in plan, however, is presented on the Ordnance Survey's First Edition 6-in. map (1873), who also describe the building as 'in ruins'.

As with much of the southwest Highlands of Scotland, the highly indented western coastline of north Knapdale is strongly influenced by the SW-NE trending orientation of its metamorphic Dalradian geology. The most important part of this sequence for the Loch Sween locality extends upwards from schistose Ardrishaig Phylites (interbedded with limestone and fine quartzite), to the more pebbly Crinan Grits quartzite (Roberts 1977, 113). The south-east shore and northeast head of Loch Sween is dominated by Crinan Grit quartzite with smaller areas associated with the Ardrishaig Phylites (and intermediate 'Ardnoe beds'; see Fig. 3b) exposed near the shore at Kilmory, and more extensive metabasalt and Tayvallich meta-limestone outcrops on the low-lying north-west shore (ibid; Stephenson and Gould 1995, 61-62). A deposit of fine white sand forms a beach known as Tràigh Bhàn (Ordnance Survey 1873; Scots Gaelic: 'White Beach') on the foreshore directly in front of Castle Sween (to the south), and a harbour has been quarried below the castle's NW tower. Elsewhere, however, the bedrock geology has had a significant effect on the topography and ecology of the surrounding area.

Knapdale is located within the birch/hazel/oak phytogeographic region of the southwest Scottish Highlands, and oak-birch woodland (with ash on more calcareous soils) is likely to have developed across the whole peninsula after the last glacial maximum (Ratcliffe and McVean 1962; Tipping 1994, Illus. 3). Protected from the west by the Inner Hebridean islands of Islay and Jura, Loch Sween presents a sheltered shallow anchorage around which an ecologically diverse mosaic of contrasting terrestrial habitats has developed. This includes an internationally important semi-natural oak woodland around the indented head of the loch to the northeast (containing 'fine growth up to $20 \mathrm{~m}$ high' on the Taynish peninsula) with some ash, hazel, birch, rowan and holly (McVean 1964, 156; Ratcliffe 1977, I, 105; II, 105; Figs. 2 and 3c); extensive arable or fertile inbye pasture on the low-lying north-western shore (including the islands of Danna and Ulva); and treeless rough grazing on the much hillier south-eastern shore below which Castle Sween is situated (Fig. 3a). Map depictions 
suggest this distinctive tripartite woodland/arable/pasture mix of habitats has prevailed around Loch Sween since at least the late sixteenth century (Blaeu 1654a; Roy 1747-55; Ordnance Survey 1873), whilst the north-western settlements associated with more calcareous geologies and arable land are a conspicuous feature of Argyll's 1481 Crown charter and Menteith's mid-fourteenth century grant to Lochawe which also included Castle Sween and its surrounding pennyland (Innes 1854, 41).

Architectural interpretations of Castle Sween suggest the primary upstanding phase of the building is significantly earlier than the surviving later medieval documents associated with the site. The core of the castle complex is comprised of a sub-square enclosure surrounded by curtain walls which display conspicuously Romanesque features in the lowest two storeys - including angle and mid-wall clasping buttresses and semi-circular archheaded entranceways framed with dressed sandstone (Fig. 4a). Later clan histories report that this 'large house' was initially constructed by 'Sween the red'; the powerful thane of Knapdale and Glassary and eponymous founder of Clann Suibhne, whose son Dufgall is found in 1261 granting churches in the south of 'Kentyr ... close by my castle of Schepehinche' (Skipness) (Sellar 1971; White 1875, 182-3). The late 12th to early thirteenth century floruit ascribed to Sween the red is, therefore, broadly consistent with the c. 1200 date generally ascribed to the architecture of the castle's primary phase curtain walls, whilst the masonry castle and chapel complex at Skipness (in the south of the lordship; see Fig. 2) was probably completed soon after (Graham and Collingwood 1923).

It is noteworthy that the masonry of the early enclosure at Castle Sween has remained largely complete throughout the building's history (cf. Ewart and Triscott 1996), although various significant secondary additions to this core structure are also clearly evident. Interpretation of these secondary phases has been subject to some revision during the twentieth century, however, with a 5-phase developmental scheme proposed by the RCAHMS (1992; Walker 2000, 184-7; Fig. 5) ultimately emerging from the 3-phase narrative presented by previous investigators (MacGibbon and Ross 1889, 59; Simpson 1967). The most significant of these revisions recasts the 2-storey NE tower block as a mid-fifteenth century (rather than thirteenth century) building constructed by MacNeill or MacMillan constables of the castle, although no very explicit reasoning in support of this revised chronology has been offered other than a tentative suggestion that 'two of the lancet window heads may be in re-use' (RCAHMS 1992, 249; Fig. 4b). In contrast, the three-storey NW tower has retained the early fourteenth century interpretation previously suggested by Simpson on the basis of perceived stylistic similarities with Breachacha Castle (Fig. 4c), with the RCAHMS discussion thereafter speculating that this structure was constructed during Castle Sween's association with John of Monteith.
A programme of excavation was undertaken in the east end of the main enclosure during 1989-1990, and although the excavators remarked that their developmental scheme did not 'correspond exactly' with the RCAHMS scheme for the upstanding structural remains (Ewart and Triscott 1996, 519), it is clear that their phasing is framed by the various constructional events which punctuated the occupational evidence. Indeed, the interrelationships between the upstanding and buried resource are methodologically intimate as, for example, dating evidence for primary occupation of the site was 'rather limited' and 'dependent on the architectural assessment of the original enclosure castle and the stratigraphical relationship of the Phase 1 deposits with succeeding ones' (ibid, 522). The architectural ascriptions presented by the RCAHMS (1992) for later phases of the site are also accepted throughout, with recognition that 'the finds from the excavation are not much help in establishing more precise dating' for the NE Tower or its inserted vaulting (ibid, 527). Significantly, however, the excavation did confirm that the earliest upstanding phase was constructed on bedrock without any evidence for an earlier castle building, and the discovery of two (Balliol 1292-96 $\&$ Edward 1305) silver pennies provides a useful early fourteenth century terminus post quem (TPQ) for the construction of the very fragmentary east range (Ewart and Triscott 1996, 521, 526; Holmes 1996 533-4). Further comparative materials evidence was also presented and will be discussed below.

Finally, in this section, it is important to note the emergence of three more recent, if limited, studies which have focussed on the character and provenance of various masonry materials used in the building's construction. This includes an innovative microscopic study of loose mortar samples from the site, which suggested these had been manufactured from a meta-limestone lime source (Hughes and Cuthbert 2000); a study of the building stone, which appeared to confirm that the same brown-grey Permian-Triassic sandstone (possibly from Muasdale Kintyre) had been used in all building phases, with some 'flaggy metamafite' blocks (Everett et al. 2015, 18-19); and an on-site survey of the castle's masonry which suggested the mortars presented phase-specific textures, with some evidence for a possible shell-lime mortar associated with the secondary west gate (Thacker 2016).

\section{On-site characterization and sampling}

On-site masonry survey during the current study supported most of the interpretations made by previous investigators with regard to the observable direct stratigraphical relationships at Castle Sween, but suggested some revision was required where no direct relationships pertain. Although subject to some qualification, therefore, the 5-phase developmental scheme presented by the RCAHMS (1992) provides a good initial framework for a summary of each of the main phases below: 


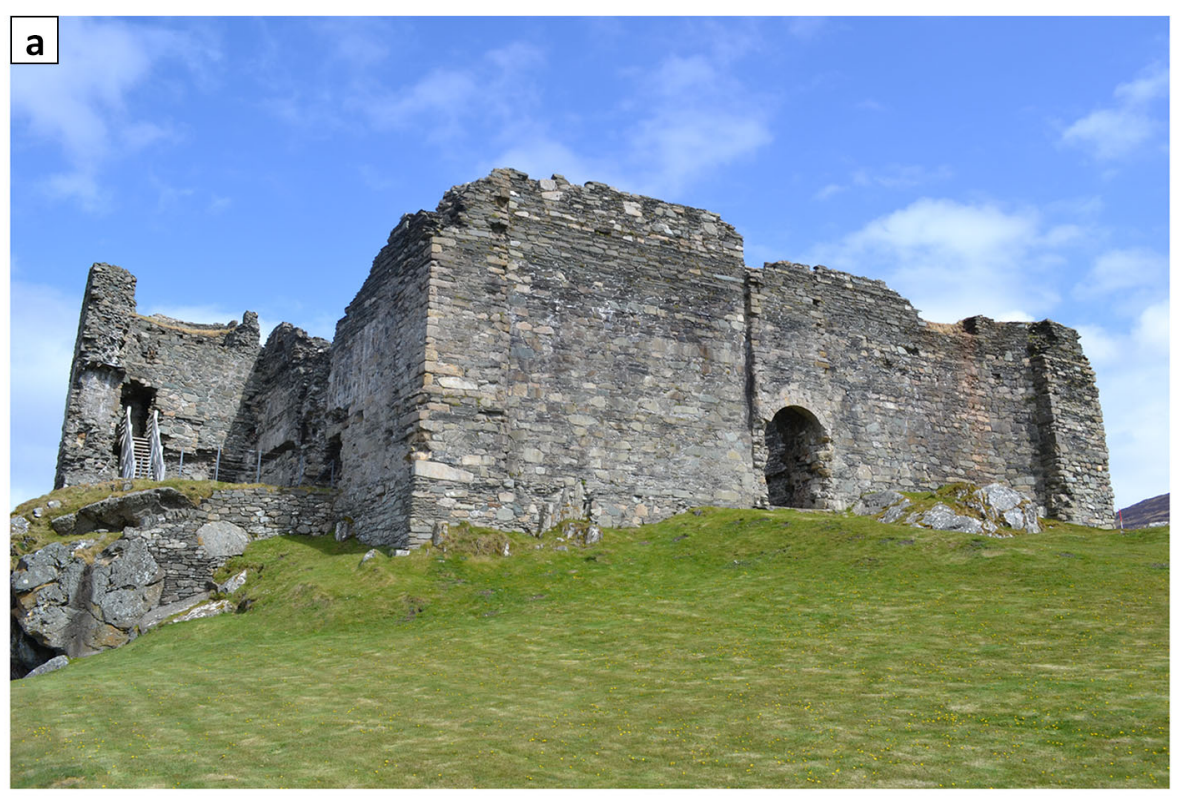

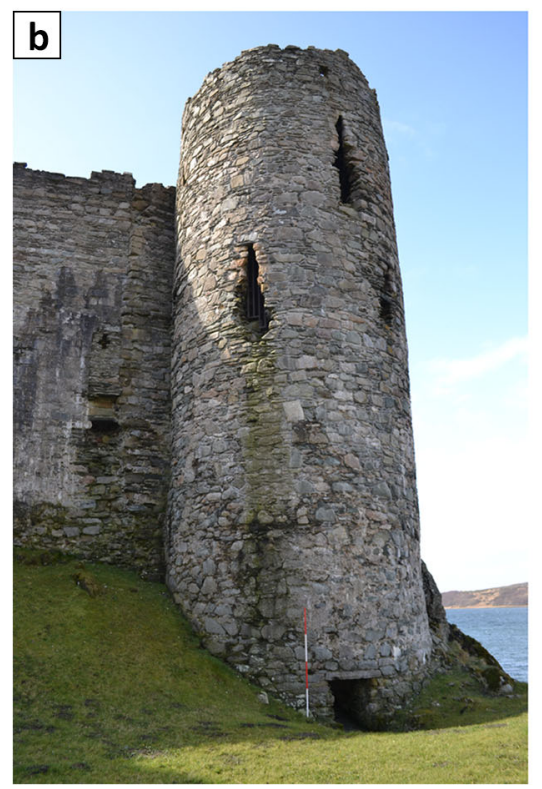

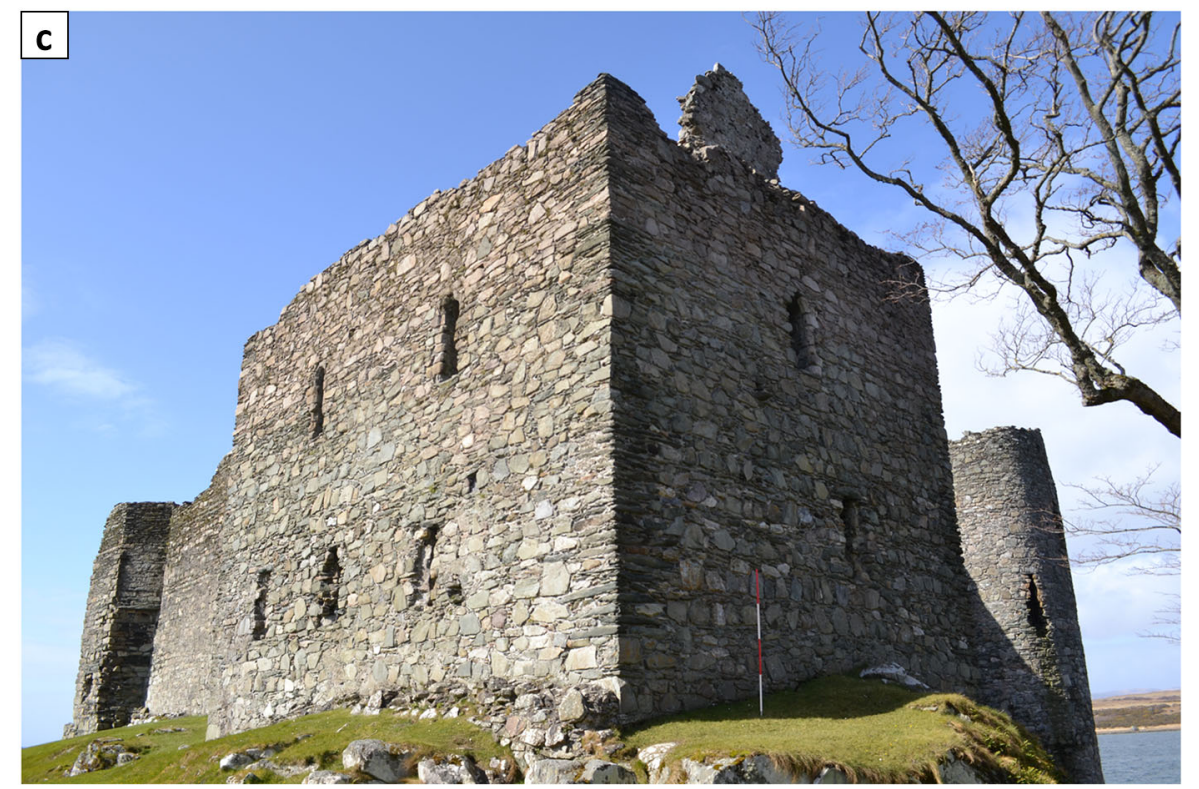

Fig. 4 a-c The main structural phases of Castle Sween. a Castle Sween from the southwest. Highlighting the sandstone-framed round archheaded main entrance and clasping buttresses of the primary phase enclosure; Romanesque features on which a c. 1200 constructional date is based. The surviving upstanding sections of the otherwise collapsed secondary West Range and NW Tower are visible on the left of this image. No scale. b Castle Sween NW Tower from the north. Perceived architectural similarities between this circular garderobe tower and a feature at

\section{Phase 1}

The Curtain Wall surrounding the main enclosure is the earliest upstanding structure within the building complex, and no underlaying upstanding phases are evident. This is also the most formal phase in terms of masonry technique, incorporating dressed sandstone details, a well-sorted mixture of rubble
Breachacha Castle, Isle of Coll, informed an early fourteenth century interpretation of this secondary NW Tower phase (Simpson $(1967,12)$. Scale $500 \mathrm{~mm}$. c Castle Sween from the northeast. Foregrounding the rubble quoins associated with the secondary NE Tower block, and the fragmentary remains of low-level buttressing along the base of the long east wall. A revised fifteenth century date for this Tower appears to be based on the suggestion that its stylistically thirteenth century sandstone window surrounds may have been re-used. Scale $500 \mathrm{~mm}$ 


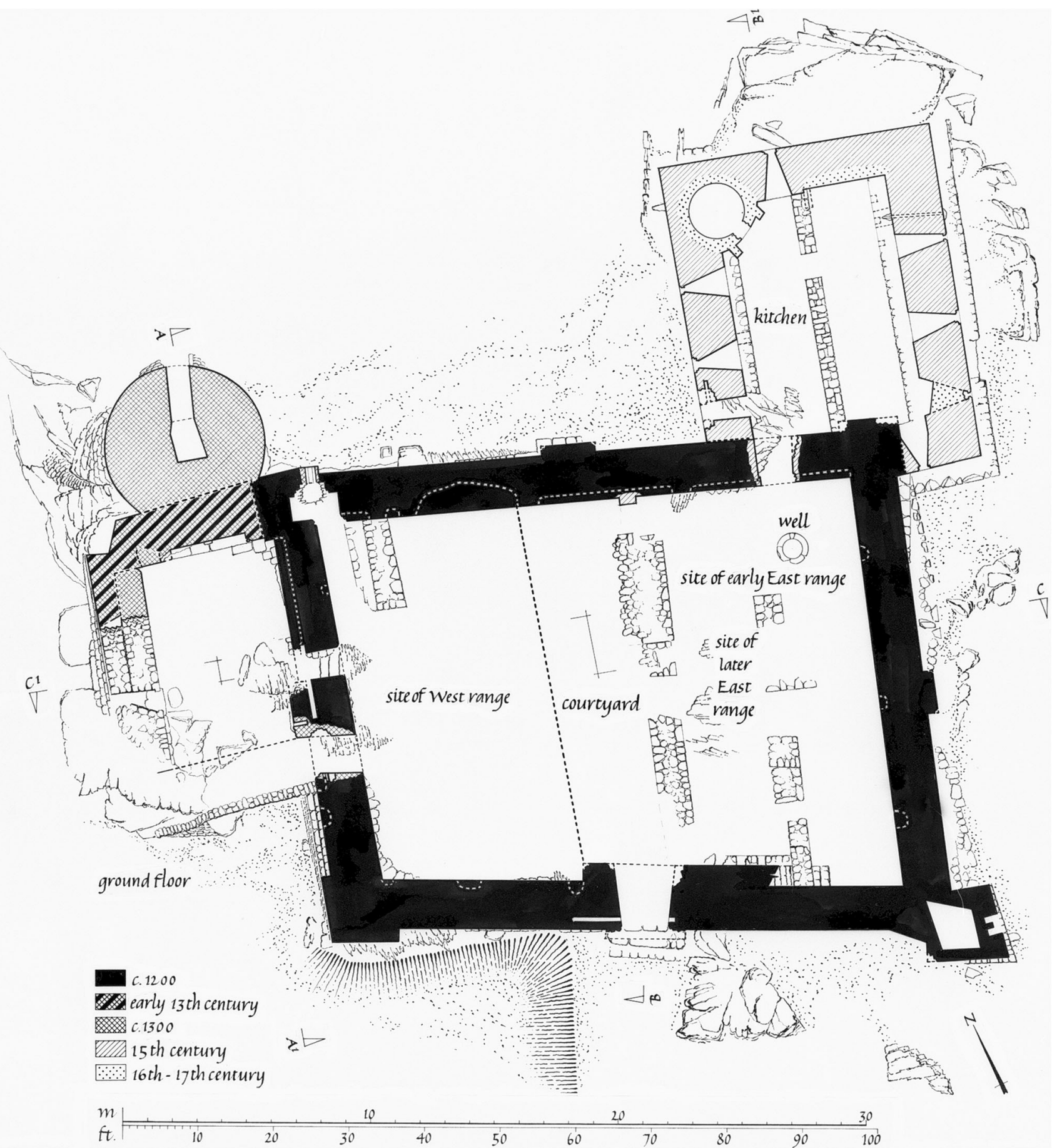

Fig. 5 RCAHMS ground-floor plan. Highlighting the five main phases attributed to the castle by the RCAHMS (1992) including the phase 1 (c.1200) curtain-walled enclosure; phase 2 (early thirteenth century) West Range; phase 3 (c.1300) NW Tower; phase 4 (fifteenth century) NE

\section{Phase 2}

The fragmentary remains of the West Range clearly abut the external face of the castle's primary west Curtain Wall northwest buttress, at ground floor level. This structure also appears
Tower; and phase 5 (sixteenth to seventeenth century) modification of the NW Tower (incl. Vaulting etc.). Image not included in Creative Commons licence; SC_753472 (C) Crown Copyright: HES

to represent a technically refined phase of construction, with narrow walls, dressed sandstone details and a fine smoothrendered internal lime mortar coating which (at least in-situ) cannot be readily distinguished from the primary phase material. Ewart and Triscott's (1996, 523) description of the surviving 


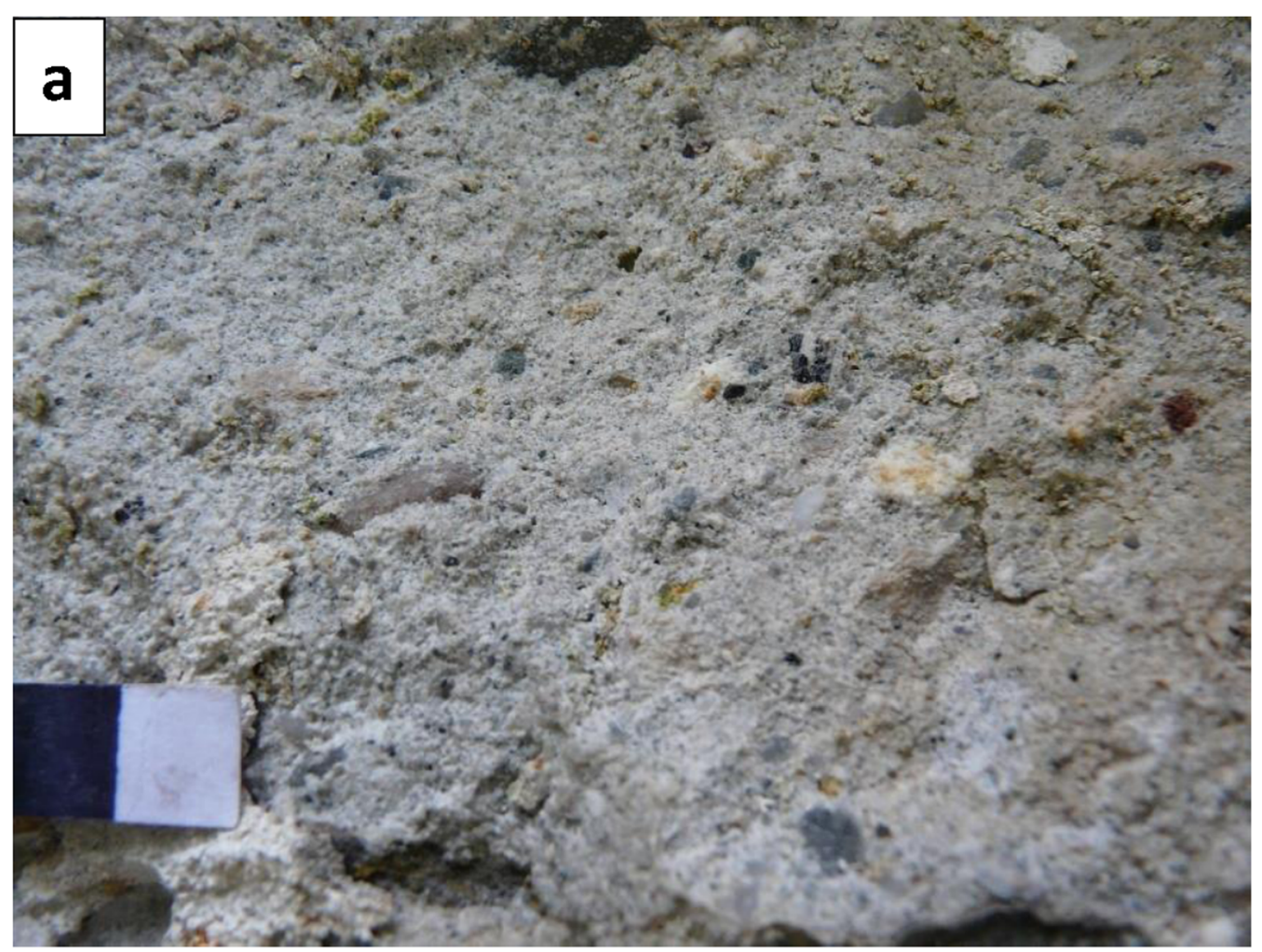

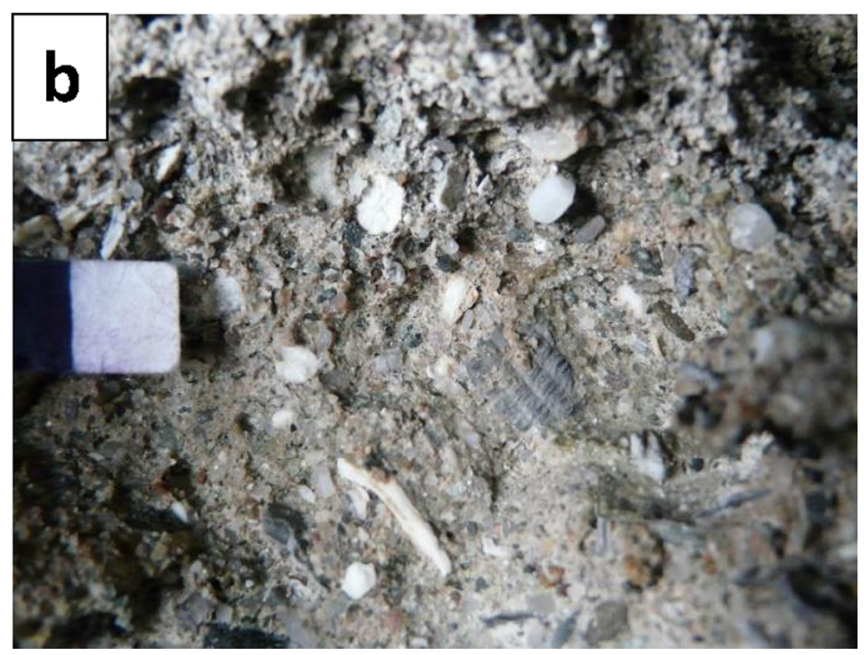

Fig. 6 a-c Exposed in situ mortars from various phases of Castle Sween. a Constructional mortar of the phase 1 east Curtain Wall. Highlighting a whitecoloured lime mortar with a predominantly very fine (sub-mm) temper and high concentration of geogenic probable limestone lime kiln relicts. This distinctive and compositionally consistent material is exposed in various continuous core, bed and coating contexts in all Curtain Walls. Scale $10 \mathrm{~mm}$. b Constructional mortar of the secondary West Gate. Highlighting abundant $O$. edulis and C. edule shell fragments. This distinctive and compositionally consistent material is exposed in continuous core, bedding and coating

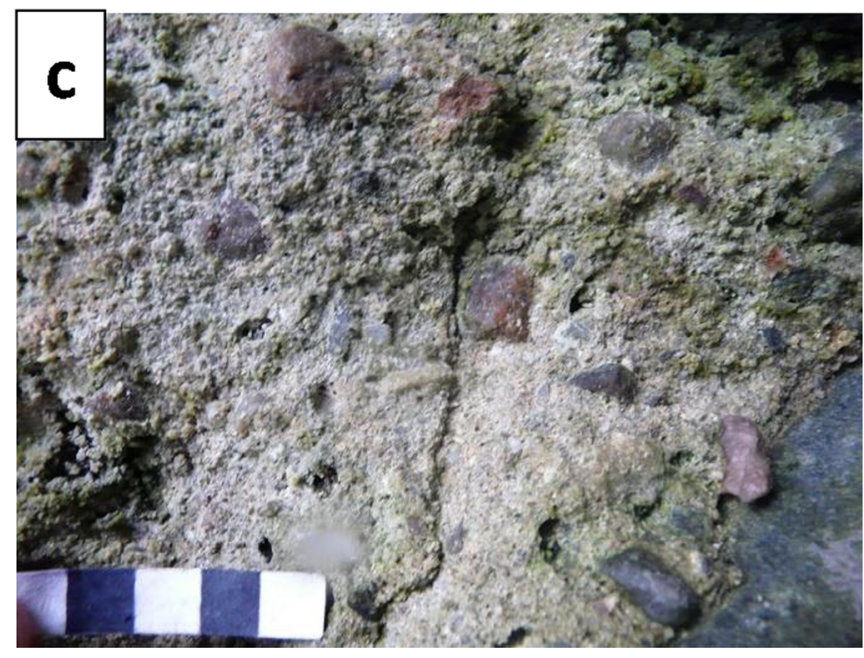

contexts in both ingoings of this secondary gate, where it directly abuts and overlays the constructional mortar of the west Curtain Wall. Scale $10 \mathrm{~mm}$. c Constructional mortar of the phase 4 NE Tower. Highlighting that the bimodal temper associated with this porous mortar includes large rounded lithic grains. This compositionally consistent material is exposed in continuous core-to-bedding contexts in the west wall of the NE Tower block. In the jambs of the south ground-floor doorway, this material directly overlays and abuts the more fine-textured constructional mortar of the north Curtain Wall. Scale $10 \mathrm{~mm}$ fragment of the (phase 2?) north range as 'bonded with a distinctive fine-grained white mortar' also appears consistent with the material binding these first two upstanding phases.

\section{Phase 3}

The NW Tower is a composite structure which overbuilds and incorporates the earlier West Range building, 
although much of this multi-storey building has now collapsed to leave large fragments of masonry tumble on the foreshore below. These fragments usefully present large exposed wall cross-sections, examination of which confirms the building previously contained a complex series of openings framed by sandstone dressings. This fabric is bound with a lime mortar which appears to be more coarsely tempered than the materials visible in phases 1 and 2, although geocarbonate and abundant wood-charcoal probable limekiln relicts are again displayed. The late West Gate is not associated with this phase, however, since that structure has been constructed with a clearly contrasting very shell-rich mortar (Fig. 6b), and this observation requires that the proposed sequence of construction on this western terrace (RCAHMS 1992, 246, 256) is revised.

\section{Phase 4}

The NE Tower abuts both main phases (1 and 2) of the Curtain Wall and is clearly abutted by phase 5 vaulting and buttresses (see below), although its relationship with the NW Tower is unknown. This building is characterized by use of mixed quartzite and alternate schistose slab rubble quoining, with dressed schist and sandstone lintelled and arcuate external ope surroundings and undressed rubble rybats internally. This mix of dressed stone provenances in external wall faces (which includes a single ground-floor sandstone sill and first-floor lancet-heads) is unusual and supports the suggestion that the sandstone has been salvaged from an earlier building. The main walling is a poorly sorted mixture of rubble blocks with some distinctive layers of upright soldier stones (similar to Duart and Kisimul), presenting a particularly informal masonry style around wall openings with undulating external wall faces and ingoings. General wall faces are largely composed of (fine and coarse) quartzite blocks, with some coarsely crystalline calcareous material but without the high concentration of flat schist levellers seen in the earlier phases. Widespread superficial consolidation obscures visibility, but a compositionally consistent constructional lime mortar remains visible in various core, bed and coating contexts. This mortar, which is now very porous and lacking durability, has been tempered with a more coarse bimodal lithic aggregate than previous phases (Fig. 6c), but again contains geocarbonate and woodcharcoal probable limekiln relicts. This material appears very similar to the mortar binding the secondary entrances through the north Curtain Wall at ground and first floor levels, where it directly abuts and overbuilds the compositionally contrasting mortar of that primary enclosure. This suggests this NE Tower and these secondary entranceways are broadly coeval, despite an apparent constructional break in the west ground-floor ingoing, and that both are coeval or later than the adjacent East Range.

\section{Phase 5}

The vaulting within the NE Tower is very clearly later than both this building and the adjacent north Curtain Wall. The structure has been bound with a lime mortar containing a high concentration of (mostly Ostrea edulis) marine shell fragments and (although questioned by earlier commentators) surviving traces of this material on the internal face of the north wall suggest this structure was previously complete. Compositionally, this mortar material appears similar to the mortar binding the low buttresses which abut the external wall faces of the NE Tower and east Curtain Wall, suggesting internal vaulting and external buttresses are coeval. Contemporaneity with the shell-rich mortar associated with the secondary West Gate also appears likely, although this latter material contains a higher superficial concentration of Cerastoderma edule (rather than O. edulis) shell and so further comparative work is required.

In summary, on-site survey suggests that the constructional materials associated with the upstanding complex have significant archaeological potential, with phasespecific variation in stone framing, constructional mortar exposure in most main phases, phase-specific variations in constructional mortar compositions, and widespread evidence that these materials are included with high concentrations of limekiln relicts. The phasing interpretation to emerge from this survey is generally consistent with that presented by the RCAHMS (1992), but also highlights evidence to suggest that construction of the NE Tower was contemporary with or post-date construction of the (now very fragmentary) East Range; the West Gate is not coeval with construction of the NW Tower; and the secondary vaulting and buttressing associated with alterations to the NE Tower may be contemporary with each other. For the purposes of the following analyses, the similarly shell-rich mortars associated with the West Gate are also (if more tentatively) ascribed to the same phase 5 as these secondary alterations to the NE Tower, in the expectation that that relationship can be investigated further in future work.

On the basis of these in situ characterisations, a sample assemblage comprised of 2 stone, 10 mortar and 71 single-entity MERLF fragments was collected and removed from Castle Sween for further lab-based analysis. For more detailed information on the contexts from which these samples derived, the reader should consult the various tables, plan drawings and annotated photographs in the ESM. 


\section{Lab-based analysis and interpretation}

\section{The mortar samples}

The sample assemblage from Castle Sween currently includes 10 mortar samples removed from the lower courses of the Curtain Wall, West Range, NW Tower tumble, NE Tower and West Gate. Microscopic examination of these materials in reflected (thick section; Fig. 7a-f) and polarized light (thin section; Fig. 8a-j) confirms that all samples display (lime) carbonate matrix-supported mixtures of (geogenic or biogenic) carbonate grains and inorganic non-calcareous rocks and minerals, whilst some also display carbonaceous woodcharcoal inclusions. A summary description of each component is presented in Table 1.

Various strands of comparative microscopic evidence suggest the geogenic carbonate grains in all mortar samples from phases 1-4 are limekiln relicts with a metamorphic provenance (cf. Elsen 2006). In reflected light, these grains present a spectrum of altered characteristics, from white or blue subangular and often elongate clasts with surviving foliated polycrystalline textures and apparently coherent grain boundaries, to increasingly buff yellow or red coloured micritic and irregular forms with rims approaching optical continuity with the supporting carbonate matrix (Fig. $7 \mathrm{a}-\mathrm{c}$ ). Examination in polarized light at higher magnification reveals these polycrystalline protoclasts are dominated by inequidimensional distributions of polygonal calcite crystals with variable levels of quartzose intraclasts, with mechanical and mineralogical alteration characterized by increasing fragmentation, micritisation of grain and crystal boundaries, loss of birefringence and cleavage, and the development of isotropic slaggy probable calc-silica reaction products (Fig. 8a-h). This carbonate evidence is consistent with that reported for loose samples from the site by Hughes and Cuthbert (2000), although the siliceous intraclast and reaction product evidence highlighted in some sections here (e.g. Fig. $8 \mathrm{~h}$ ) contrasts with the very pure carbonate evidence previously described (cf. Leslie and Hughes 2004; Thacker et al. 2019). In addition to the range of textural characteristics and relationships with the supporting carbonate matrices, these geogenic and biocarbonate grains are often much larger than the fine materials dominating the (more durable generally quartzose) non-calcareous fraction of each section, so suggesting these form separate components of each mortar's composition and supporting their identification as limekiln relicts and temper aggregates respectively.

In striking contrast to the samples described above, the sections from phase 5 samples CSA.05 \& CSA.06 display abundant marine shell fragments, and almost no geocarbonate evidence (Fig. 7d-f). Various biostructural features visible in reflected and polarized light indicate these shell fractions are dominated by $C$. edule (including distinctively ribbed and protein-rich mesosectostraca; Bøggild 1930; Mitchell 1935) with some $O$. edulis (with alternate foliated and chalk layers). These biogenic clasts also display a range of altered textures analogous to those presented by the meta-limestone clasts in phase 1-4 samples described above. This includes fracturing, crazing, discolouration (hydrocarbon dissociation), loss of biostructure with increased micritisation and ultimately optical, physical and pectoral continuity with the surrounding carbonate matrix (Fig. 8i, j). Whilst section CSA.06a also contains shell fragments which are more coarse and angular than the non-calcareous temper fraction, both mortar samples display remarkably high concentrations of very fine $(0.05 \mathrm{~mm})$ shell fragments which merge with the supporting carbonate matrices.

The quartz-rich metamorphic mineralogy of the noncalcareous temper fraction is broadly similar in all mortar sections and the only carbonaceous possible MERLF evidence noted was wood-charcoal. The altered marine shell evidence in the West Gate samples requires further work, but from a relative chronological perspective, the geocarbonate and biocarbonate evidence is almost mutually exclusive across the assemblage and so clearly phase specific. Together with variations in the character of the surviving meta-limestone evidence (particularly relative abundance and purity) and non-calcareous temper fraction (size and distribution), these mortar sections display distinctive compositions consistent with the phasing scheme proposed on site. Accepting that these samples were selected to be representative, and so there is some circularity of interpretation, the multi-scalar consistency of this evidence mitigates issues associated with the characterization of materials from very small samples and supports MERLF sample context identification.

\section{The stone samples}

The sample assemblage from Castle Sween currently includes 2 stone samples, with a loose (ex situ) fine-grained grey-buff coloured sandstone sample collected from the north Curtain Wall (CSA.11) and a coarsely crystalline white-coloured calcareous fragment of a large block on the nearby foreshore (CSA.12) which reacted vigorously with cold 2 M HCL. A summary of the character of these samples in thin section is presented in Table 2 with reference to Figs. 9a and 9b.

On the basis of this analysis, sandstone sample CSA.11 can be characterized as a moderately porous fine to medium grained subfeldspathic arenite. Although clearly affected by weathering, this interpretation is broadly consistent with that reported from loose samples by Everett et al. (2015, 18-19, 44), who also suggested this was likely to have been sourced from Permian-Triassic Bellochantuy Bay Formation outcrops exposed at Muasdale in Kintyre. Attention is drawn to the 

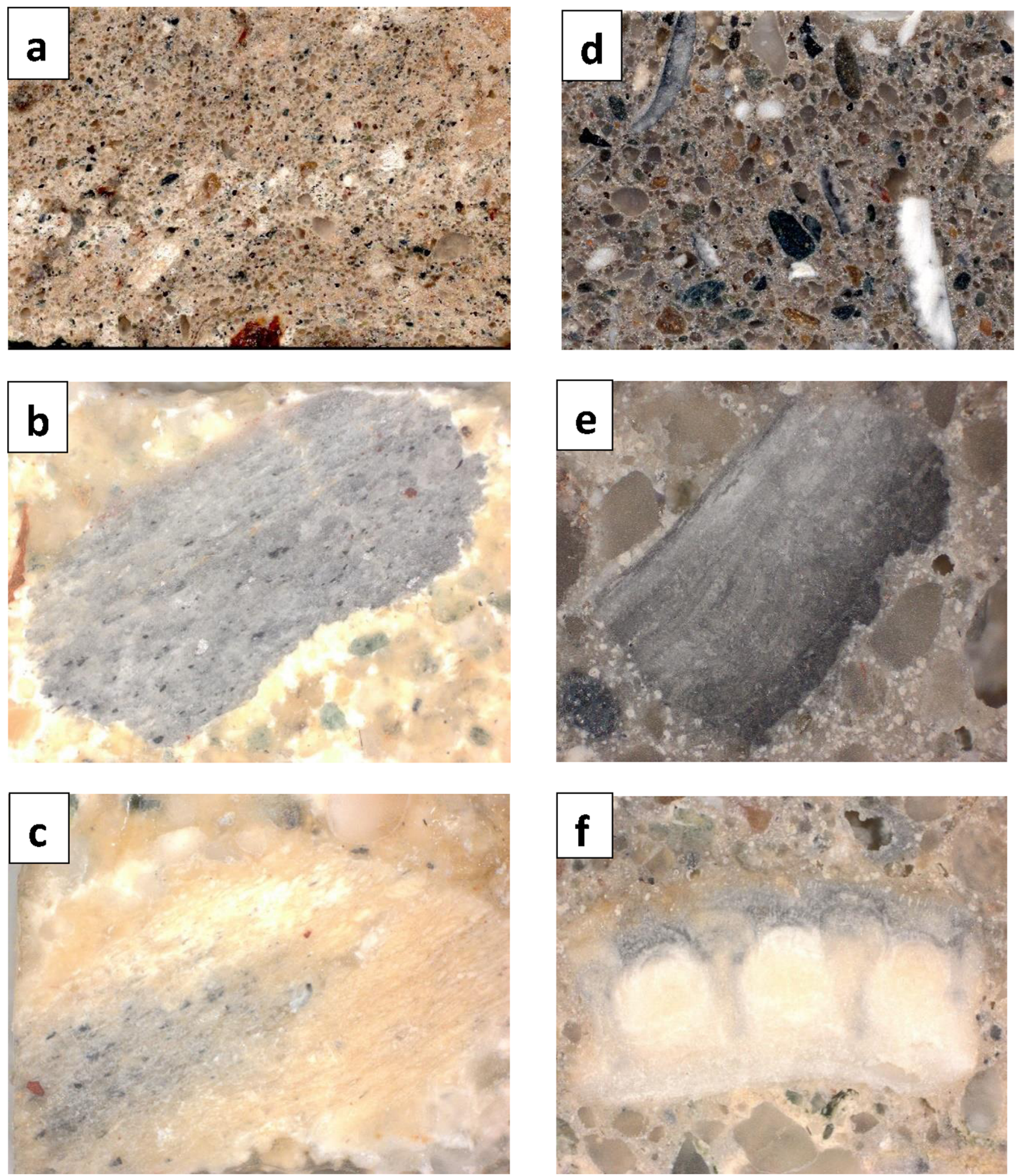

locally high concentrations of degraded mica in this clast which in some contexts surrounds almost all other grains and is degrading to a clay, since this may provide a context for the 'orange bands' noted within some of these eroded blocks on site by the RCAHMS ( 1992, 250; see also
Everett et al. 2015, 18-19, 44) and during building survey for the current project. Calcareous sample fragment CSA.12 can be characterized as a texturally heterogeneous impure meta-limestone. 
Fig. 7 a-f Scans and photomicrographs of mortar thick sections from Castle Sween in reflected light. Highlighting mutually exclusive evidence for geogenic and biogenic carbonate inclusions. a Scan detail of thick section CSA.09b. Highlighting fine texture and abundant elongate white/buff geogenic carbonate inclusions. Field of view: $36.3 \times 24.8 \mathrm{~mm}$. b Photomicrograph detail of thick section CSA.03b. Highlighting an elongate polycrystalline geocarbonate grain. Field of view: $8 \times 7 \mathrm{~mm}$. c Photomicrograph detail of thick section CSA.03b. Highlighting a more highly altered geocarbonate grain with relict polycrystalline core. Field of view: $4.5 \times 3.5 \mathrm{~mm}$. d Scan detail of thick section CSA.06a. Highlighting a more coarse poorly sorted texture and abundant marine shell fragments. Field of view: $29.2 \times 23 \mathrm{~mm}$. e Photomicrograph detail of thick section CSA.06b. Highlighting discolouration in a $C$. edule shell fragment. Note also abundant very fine shell fragments. Field of view: $3.5 \times 2.5 \mathrm{~mm}$. f Photomicrograph detail of thick section CSA.06b. Highlighting a $C$. edule shell fragment with an incoherent grain boundary and relict biostructure. Field of view: $7 \times$ $5.5 \mathrm{~mm}$

\section{The MERLF samples}

The MERLF assemblage from Castle Sween is currently comprised of 71 samples, removed from the lower courses of the Curtain wall, NW Tower tumble, lower courses of the NE Tower and West Gate. The assemblage is completely dominated by wood-charcoal, and no evidence for other fuel types was noted during building survey, thin section or archaeobotanical analysis. Microscopic examination indicates the assemblage is comprised of five different taxa, including Betula (Fig. 10a), Corylus, Fraxinus, Ilex and Quercus (Fig. $10 \mathrm{~b}$ ), and is dominated by Quercus (65\%; see Table 3).

Accepting sample quantities and distributions must be considered, striking contrasts in the character of the MERLF assemblage from each structural phase are also evident. The Curtain Wall assemblage is large, reasonably well distributed (east, west and north Curtain Walls), from a broad range of core, bed and coating masonry contexts, and dominated by Quercus $(72 \%)$ and fragments with no apparent biostructural curvature $(77 \%)$. Perhaps more significantly, given that both taxa are long-lived and ring porous, $96 \%$ of this assemblage is comprised of Quercus and Fraxinus. The NW Tower assemblage is moderately sized, dominated by core samples from different tumble blocks, with a majority of Quercus (55\%) and fragments with no apparent biostructural curvature (56\%), but including a significant fraction of Betula (33\%). The NE Tower assemblage is small (reflecting limited visibility/ widespread consolidation) and dominated by Corylus (67\%) and Betula (33\%).

A sub-assemblage of 10 single-entity MERLF samples from four different structural phases was selected for AMS radiocarbon analysis (see Table 4).

\section{Statistical analysis of chronological data}

Unfortunately, the radiocarbon result from West Gate sample CSA.4e is clearly very much earlier than the phase from which it was removed and will not therefore be considered any further. Moreover, the remaining three structures are associated with results which are not consistent at 5\% significance level (phase $1-T=11.6, T(5 \%)=6.0, \nu=2$; phase $3-T=10.3$, $T^{\prime}(5 \%)=6.0, \nu=2 ;$ phase $4-T^{\prime}=9.7, T^{\prime}(5 \%)=6.0, \nu=2$; Ward and Wilson 1978), and it is not thereby possible to demonstrate that these fragments are likely to be of the same age. Importantly, however, with the exception of a slight overlap between Curtain Wall sample CSA.2t and NW Tumble sample CSA.1g, these results do fall into three distinct clusters which appear to support the phasing interpretation presented by the RCAHMS for the four main periods of construction. This is perhaps most particularly significant regarding the (phase 3) NW Tower and (phase 4) NE Tower, which are not directly stratigraphically related, and that relationship will be considered further below.

A Bayesian model was constructed around these nine radiocarbon determinations to generate date range estimates for the constructional completion of each of the four phases of Castle Sween (Fig. 11; Table 5; see ESM for model script). Within this model, the radiocarbon dates are constrained within the separate phases suggested by site survey and lab-based mortar analysis. As also suggested by site survey, the NW Tower and NE Tower distributions are not related to each other directly in the model, and an 'Order' function is included to calculate the probability that the NW Tower precedes the NE Tower on the basis of the radiocarbon data and stratigraphic relationships to phases 1 and 2 alone. The SMCCCP is continuing to refine Bayesian approaches to MERLF radiocarbon data which may be subject to inbuiltage but, following recent work at a number of other medieval castle sites across Scotland (Thacker 2020), each of the dates from Castle Sween has been situated within OxCal 'General' Outlier and 'Charcoal' Outlier models (Bronk Ramsey 2009b) depending on archaeobotanical character. No historical or architectural-typological data is included in the current 'standalone' model but will be discussed below.

This 'standalone' Bayesian model 1a suggests construction of the primary Curtain Wall at Castle Sween was completed in 1070-1315 cal AD (95.4\% probability) probably $1170-1250$ cal AD (68.2\% probability; Castle Sween Construction Phase 1; Fig. 11; Table 5); construction of the West Range was completed 1165-1410 cal AD (95.4\% probability) probably $1210-1310$ cal AD $(68.2 \%$ probability; Castle Sween Construction Phase 2; Fig. 11; Table 5); construction of the NW Tower was completed 1225-1600 cal AD (95.4\% probability) probably 1250 1380 cal AD (68.2\% probability; Castle Sween Construction Phase 3; Fig. 11; Table 5); and construction of the NE Tower was completed 1285-1590 cal AD (95.4\% probability) probably $1295-1420$ cal AD $(68.2 \%$ 

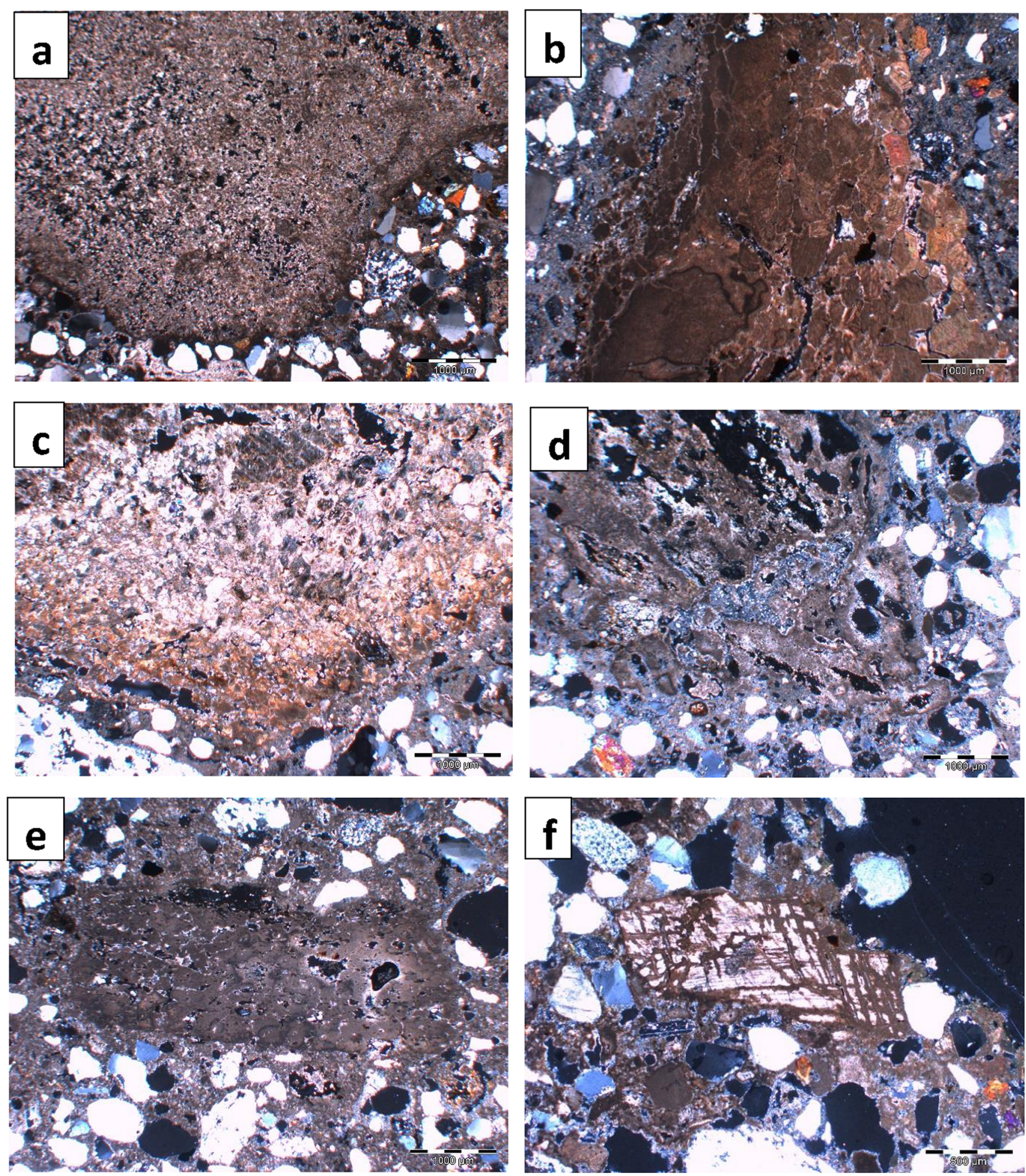

probability; Castle Sween Construction Phase 4; Fig. 11; Table 5). The model suggests there is a $72 \%$ probability (Castle Sween Phase 3-4 Probability; Table 6) that construction of the (phase 3) NW Tower was completed before construction of the (phase 4) NE Tower.

\section{Conclusion}

Castle Sween is a geocultural sedimentary structure which presents distinctive phase-specific suites of masonry evidence. This includes contrasting architectural designs, masonry styles, stone types and mortar 

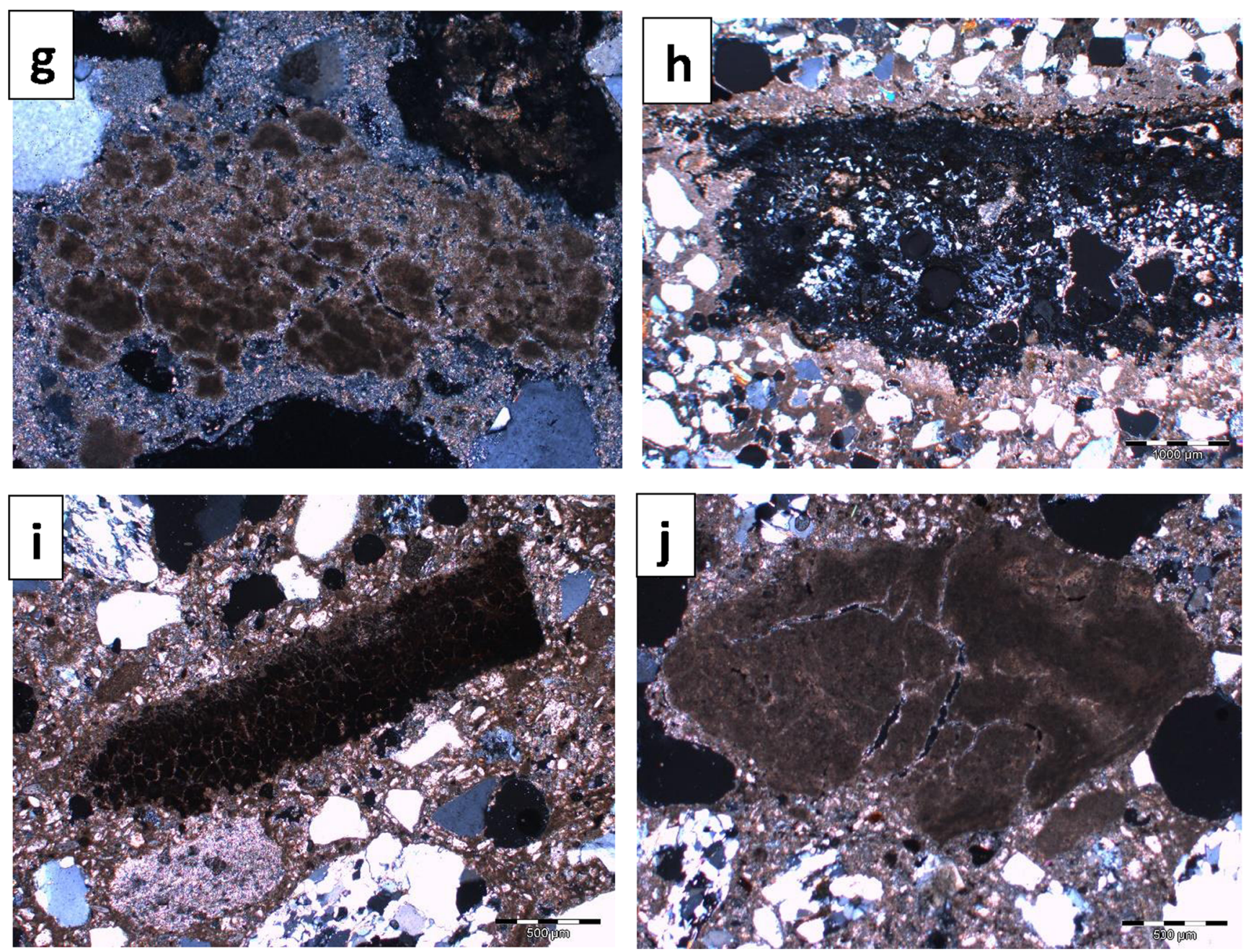

Fig. 8 (continued)

4 Fig. 8 a-j Photomicrographs of mortar thin sections from Castle Sween in polarized light. Highlighting the character of various geogenic and biogenic carbonate inclusions. a Large subrounded fine-textured geocarbonate grain in thin sectionCSA.02bsurroundedbyasubmillimetric predominantlyquartzosetemper. Scale $1 \mathrm{~mm}$;XPL.bLargeangulargeocarbonategraininthinsectionCSA.03awith relicpolycrystallinecalcite crystals, surrounded byapredominantlysubmillimetric quartzosetemper.Scale $1 \mathrm{~mm}$;XPL.cLargesubroundedgeocarbonategraininthin section CSA.04b with somerelictpolycrystallinity (including calcite cleavageevidence). Bimodal quartzose temper. Scale $1 \mathrm{~mm}$; XPL. d Large irregular geocarbonate grain in thin section CSA.07b with quartzose intraclasts and calcsilica reactions. Fine submillimetric quartzose temper surrounding. Scale $1 \mathrm{~mm}$; XPL.eLargeelongategeocarbonategraininthinsectionCSA.09b.Predominantly micritictexturewithfinequartzoseintraclasts. Finesubmillimetrictempersurrounding.Scale $1 \mathrm{~mm}$;XPL.fLargeelongatesubangulargeocarbonategraininthinsection CSA.10bwithrelictcalcitepolycrystallinitybirefringenceandcleavageandmicritic grain and crystal boundaries. Scale $1 \mathrm{~mm}$; XPL. g Large irregular/subrounded geocarbonategrain in thin sectionCSA.01b; predominantlymicritic butwith some relictpolygonalpolycrystallinity.Scale $1 \mathrm{~mm} ; X P L . h L a r g e e l o n g a t e g e o c a r b o n a t e$ grain in thinsectionCSA.08awithirregulargrainboundary. Thisclastisdominated by isotropic probable calc-silica reaction product. Scale $1 \mathrm{~mm}$; XPL. i Large subangular biocarbonate grain in thin section CSA.05a; crazed and discoloured probable C. edule grain surrounded by poorly sorted quartzose temper. Scale $1 \mathrm{~mm}$;XPL.j Large subrounded biocarbonate grain in thin section CSA.06a; predominantlymicritictexturewithsomesurvivingbiostructure. Poorlysortedquartzosetemper. Scale $1 \mathrm{~mm}$;XPL compositions, whilst radiocarbon analysis of selected single-entity MERLF fragments fossilized within various phases has returned clusters of dates which are generally consistent with the structure's stratigraphy. Bayesian analysis of this radiocarbon data has generated standalone chronological estimates for completion of the Curtain Wall, West Range and NW Tower which are consistent with previous art-historical interpretations of these buildings, and supports the suggestion that construction of the NE Tower post-dates the NW Tower. Once more, the narrower $68.2 \%$ probability estimates presented by this 'standalone' model are particularly convincing (Table 7; cf. Thacker 2020).

\section{Discussion}

The $1170-1250 \mathrm{cal} A D(68.2 \%$ probability) constructional estimate generated for the primary phase enclosure of Castle 
Sween is consistent with the c. 1200 date previously ascribed to the structure on the basis of its Romanesque architecture and Clann Suibhne oral tradition. There is no evidence to link the initial construction of this remarkable building to the Scottish Crown. The 1250-1380 cal AD (68.2\% probability) constructional estimate generated for the NW Tower is consistent with the c.1300 previously ascribed to this building. This date is also consistent with the cross-slit openings associated with this phase and somewhat similar features in the nearby castles of Skipness (Graham and Collingwood 1923, 276) and Brodick (Arran) provide a possible architectural association with Monteith. It appears likely the Menteiths gained title to the castle and surrounding lordship during the reign of Alexander III and, despite the English Crown's interest during the Wars of Independence, continued to hold the building into the mid-fourteenth century. The 1295 1420 cal $A D$ (68.2\% probability) estimate generated for the construction of the NE Tower is earlier than the most recent interpretations of this building and appears inconsistent with traditions suggesting this block was initially constructed by Alexander MacMillan - a reported heir to the MacNeills by marriage who can only have been constable of the castle during the 1472-1481 period (Munro and Munro 1986, 268). This estimate will be reconsidered in future work, but currently suggests the building is broadly contemporary with the adjacent east range (accepting that the Robert III groat discovered during excavation probably relates to later occupation of that structure; Holmes 1996, 534) and connecting entranceways between these two buildings at both ground and first floor levels clearly indicate these structures were at least occupied in the same period. The demolition of an earlier north range to make way for the east range building also provides a possible context for the salvaged thirteenth century lancet-headed windows within the east wall of the tower structure whilst other blocks may have been robbed from the primary NE angle clasping buttress. It remains possible that this building was patronized by the MacDonald lords of the Isles after 1375, and this estimate also allows for the possibility that MacMillan oversaw the secondary modifications to the NE Tower (vaulting, buttresses and West Gate) during the reported late fifteenth century 'stuffing' of the castle with rebels and arms by the lord of the Isles. Further materials analysis including radiocarbon dating, however, is clearly required to further inform that suggestion.

Each of the distinctive stratigraphic layers presented by the surviving monument is dominated by materials sourced from the immediate locality, and exploited resources from outside of the Knapdale lordship are currently limited to sandstone. Sandstone was freshly quarried and dressed for construction of the first three phases of the castle's construction, at least, and the texture of a fragment collected from the north Curtain Wall during this study is consistent with previous suggestions that this material has a Permian-Triassic provenance associated with outcrops at Muasdale in neighbouring Kintyre (39 km SSW of Castle Sween; Everett et al. 2015). A charter relating to the parish church of Killean suggests the lordship of Kintyre was held by Reginald MacSorley before 1222 (Duncan and Brown 1957, 219) and yet the sandstone dressings surviving in the late twelfth century primary phase of that church building, which is situated only $4.5 \mathrm{~km}$ NNE of Muasdale, have been associated with outcrops in Aran or Northern Ireland (RCAHMS 1971, no. 287). Further work is required, but on current evidence it appears the distinctive grey-coloured sandstone associated with Kintyre was first quarried for the secondary chancel at Killean or perhaps even for the (c.1200) construction of Castle Sween. Without knowing how the Clann Suibhne or their masons negotiated access to the Muasdale quarries, that the Menteiths held both Kintyre and Knapdale by the very early fourteenth century is likely to have facilitated continued use of the primary phase sandstone source for construction of the NW Tower. Further work is required to establish whether any freshly quarried sandstone was employed during construction of the NE Tower at Sween, although the suggested use of salvaged sandstone (an interpretation now supported by the radiocarbon evidence presented above) and widespread use of the more locally available quartzite and schist rubble to frame the walls of this phase 4 and 5 structure, appears to represent a conspicuous contrast with the 'lavish use' of sandstone in the primary phase enclosure (RCAHMS 1992, 250) and NW Tower. Indeed, the schist slab quoining of the NE Tower displays superficial rounded pockets of erosion identical to those visible on local foreshore outcrops.

The above study has examined a reasonably comprehensive preliminary assemblage of mortar samples and presented evidence to suggest these were manufactured from locally available inorganic materials of coastal/metamorphic character in all phases. A metamorphic limestone was exploited for lime manufacture in the first four phases of castle construction, and it is likely all of these materials were tempered with quartz-rich aggregates from the foreshore at nearby Tràigh Bhàn (175 m SW of Castle Sween). The constructional mortar associated with the NE Tower is again distinctive, however, with the phase 4 constructional mortar presenting evidence for increased porosity and impurities in the lime source, and the phase 5 alterations associated with a shell-rich possible shelllime mortar. Petrographic analysis of sample CSA.12 has demonstrated that the large angular block on the foreshore adjacent to Tràigh Bhàn (CSA.12) presents a similarly impure meta-calcareous composition, although a range of limestone sources (which may match relict evidence from earlier phases more closely) were historically available elsewhere in the locality and further sampling and comparative analysis is required to inform this interpretation. No obvious source for the shell fragments noted in the later mortars at Castle 
Table 1 Site context and character of the inclusions contained within 10 mortar samples removed from five phases of Castle Sween

\section{Phase Section code Inclusion type Inclusion description}

1 CSA.02b Carbonate Moderate to high concentration of geogenic carbonate inclusions ranging from large subrounded micritic to microcrystalline brown-coloured grains $\leq 10 \mathrm{~mm}$ (Fig. 8 a), to isolated but widely distributed angular polygonal calcite crystals $\leq 0.6 \mathrm{~mm}$ with surviving cleavage and various levels of surviving birefringence. Larger micritic grains are generally elongate and there is a range of evidence for subangular clasts with relict foliated inequidimensional polycrystalline textures (particularly in thick section). This evidence is consistent with a pure meta-limestone protoclast, with rare evidence for quartzose intraclasts Irregular pores throughout the mortar are lined with secondary microcrystalline calcite throughout.

No biogenic (marine shell) fragments noted.

Inorganic Bimodal mix $\leq 9 \mathrm{~mm}$, dominated by subangular submillimetric quartz, with subrounded mica-schist, non-calcareous weathered dolerite; plagioclase, mica and clinopyroxene $\leq \mathbf{1 ~ m m}$. Very low concentration of subrounded quarzite and subangular quartz $\leq 3-9 \mathrm{~mm}$.

Carbonaceous Low concentration of wood-charcoal fragments incl. Longitudinal lens $3 \times 0.2 \mathrm{~mm}$ with ring porosity.

CSA.03a Carbonate

High concentration of angular to irregular geogenic carbonate grains $\leq 12 \mathrm{~mm}$. A continuous and wide range of textures are presented from brown-coloured and micritic, to polycrystalline clasts of oriented inequidimensional $(0.2-1.5 \mathrm{~mm})$ high birefringence calcite crystals separated by triple-point junctions (Figs. $7 \mathrm{~b}, \mathrm{c}$ and $8 \mathrm{~b}$ ). A poorly sorted mix of subangular quartzose intraclasts $\leq 0.6 \mathrm{~mm}$ is also evident and consistent with a meta-limestone protoclast.

No biogenic (marine shell) fragments present.

Inorganic Poorly sorted to bimodal mix $\leq 11 \mathrm{~mm}$, dominated by angular to subrounded quartz, quartzite, non-calcareous chlorite-schist, mica, olivine, chlorite, clinopyroxene (alkali-rich)

$\leq \mathbf{1 ~ m m}$. Minor concentrations schist and calc-chlorite-schist $\leq 11 \mathrm{~mm}$.

Carbonaceous Moderate concentration of wood-charcoal fragments grading to $1.5 \mathrm{~mm}$, including a fragment with probable ring porosity.

CSA.04b Carbonate High concentration of subrounded to irregular geogenic carbonate grains $\leq 10 \mathrm{~mm}$ (Fig. $8 \mathrm{c}$ ). These display a continuous and wide spectrum of textures from micritic and brown-coloured to fine polycrystalline clasts comprised of largely unaltered high birefringence inequidimensional calcite crystals $\leq 1.1 \mathrm{~mm}$. Quartzose intraclasts $\leq 0.15 \mathrm{~mm}$ are also present and consistent with a fine-textured meta-limestone protoclast.

No biogenic (marine shell) fragments present.

Non-calcareous Bimodal mix dominated by angular to subrounded submillimetric quartz, with subrounded quartzite, chlorite-schist, dolerite, feldspar, chlorite, clinopyroxene (with some twinning) $\leq \mathbf{1 ~} \mathbf{m m}$. Single subrounded quartzite grain $\leq 4 \mathrm{~mm}$.

Carbonaceous None noted.

CSA.07b Carbonate

High concentration of subrounded to irregularly shaped geogenic carbonate clasts $\leq 10 \mathrm{~mm}$; generally purely micritic with incoherent grain boundaries, but also including lenses of well-developed glassy isotropic probable calc-silica reaction products suggestive of silicious intraclasts (Fig. 8d). Some rare highly birefringent calcite crystals with cleavage textures and poorly sorted mixtures of quartz and mica intraclasts. All consistent with a meta-limestone protoclast.

No biogenic carbonate (marine shell) grains present.

Inorganic Bimodal mix dominated by angular to subrounded quartz, subrounded schist, feldspar, mica, chlorite, non-calcareous clinopyroxene, olivine $\leq \mathbf{0 . 5} \mathbf{~ m m}$. Schist $\leq 1 \mathrm{~mm}$ and single subangular dolerite grain $\geq 20 \mathrm{~mm}$.

Carbonaceous None noted.

2 CSA.09b Carbonate

High matrix volume and very high concentration of geogenic elongate carbonate grains $\leq 9 \mathrm{~mm}$ long with micritic generally pure carbonate textures and incoherent grain boundaries. Elongate cells of micrite, silt size layers of quartzose intraclasts parallel to main grain axis, and some rare evidence for angular polygonal crystal shapes with relict calcite cleavage suggest a meta-limestone protoclast (Fig. 8e).

Rare fine curving probable marine shell fragments $3 \times 0.15 \mathrm{~mm}$.

Inorganic Well-sorted to bimodal mix dominated by angular to subangular quartz grains with some subrounded non-calcareous chlorite- and mica-schist and rounded plagioclase feldspar $\leq \mathbf{0 . 5} \mathbf{~ m m}$, with a very low concentration of larger subrounded clasts to $3 \mathrm{~mm}$.

Carbonaceous None noted.

CSA.10b Carbonate Very high concentration of elongate geogenic carbonate grains $\leq 8 \mathrm{~mm}$ long. With micritic textures and irregular and incoherent grain boundaries, these grains are often close to optical continuity with the supporting (lime) carbonate matrix. The elongate shape, low concentrations of quartz intraclasts, fine lenses of parallel probable calc-silica reaction products, and some relict crystal polygonality, cleavage and high birefringence (Fig. 8f), are all consistent with a meta-limestone protoclast.

Inorganic

non-calcareous 
Table 1 (continued)

\section{Phase Section code Inclusion type Inclusion description}

Well-sorted mix dominated by angular quartz $\leq \mathbf{0 . 5} \mathbf{~ m m}$; with more minor subangular to subrounded mica-schist and chlorite-schist, possible dolerite, plagioclase, clinopyroxene. One grain of quartz grades to $2.8 \mathrm{~mm}$. CSA.01b Carbonate

None noted.

Moderate concentration of elongate subrounded to irregular geogenic carbonate grains $\leq \mathbf{1 0} \mathbf{m m}$ long. Ranging from homogenous micritic brown-coloured textures with irregular and incoherent grain boundaries to polycrystalline grains comprised of high birefringent calcite crystals with triple-point junctions and oriented layers of contrasting grades. Intraclast grains include irregular quartzose $\leq 1.3 \mathrm{~mm}$ and subangular quartz $\leq 0.2 \mathrm{~mm}$. Consistent with a meta-limestone protoclast.

No biogenic (marine shell) fragments present.

Inorganic Poorly sorted (very well graded) mix dominated by subrounded-subangular clasts $\leq 6 \mathrm{~mm}$, including non-calcareous mica-schist, chlorite-schist, quartzite and dolerite/gabbro, with monocrystalline quartz, weathered plagioclase and mica.

Carbonaceous None noted.

4 CSA.08a Carbonate

Porous/voided mortar material with a low to moderate concentration of irregularly shaped, elongate, highly altered geogenic carbonate clasts $\leq 12 \mathrm{~mm}$, with large areas of isotropic probable calc-silica reaction products (Fig. 8h). Relict polycrystalline textures and poorly sorted quartz intraclasts suggest a meta-limestone protoclast.

No biogenic carbonate (marine shell) grains noted.

Inorganic High concentration poorly sorted (very well graded) mix of non-calcareous lithic grains, including non-calcareous subrounded elongate quartzite and mica-schist $\leq 18 \mathrm{~mm}$, subangular to subrounded monocrystalline quartz, schist, feldspar $\leq 2 \mathrm{~mm}$, with minor subrounded clinoproxene $\leq 0.5 \mathrm{~mm}$.

Carbonaceous None noted.

5 CSA.05a Carbonate

Very coherent mortar material with high concentration of subangular to irregular biogenic marine mollusc shell fragments $\leq 4 \mathrm{~mm}$, with ribbed and proteinous mesectostraca layers characteristic of $C$. edule shell fragments, lower fractions of $O$. edulis lamellae, and abundant shell micro-fragments $\leq 0.05 \mathrm{~mm}$. These fragments display a range of evidence for alteration, including: fracturing and crazing; discolouration caused by the dissociation of the proteinous matrix (Fig. 8i); loss of internal biostructure and grain boundaries; increasing micritisation and ultimately optical, physical and textural continuity with the supporting carbonate (lime mortar) matrix. Subrounded micritic carbonate grains are also present.

$2 \times$ irregularly shaped and altered geogenic calcareous grains noted to $1 \mathrm{~mm}$ with developing opacity and fine quartz intraclasts, but no evidence for calcite crystals or polycrystalline clasts noted.

Inorganic Poorly sorted mix of angular to rounded grains $\leq 4 \mathrm{~mm}$. Including larger rounded to subrounded non-calcareous chlorite-schist, mica-schist, dolerite/gabbro and finer angular to subangular quartz, mica-schist, plagioclase and mica.

Carbonaceous Low-moderate concentration of wood-charcoal inclusions including a 1.5-mm-long ring porous grain.

CSA.06a Carbonate Coherent mortar material with a high concentration of angular to irregular biogenic marine molluse shell fragments $\leq 12 \mathrm{~mm}$ with ribbed and proteinous mesectostraca layers characteristic of $\boldsymbol{C}$. edule shell, with some $O$. edulis laminae (Fig. 7d-f). These shell fragments display a range of textural evidence for secondary alteration, including: fracturing; discolouration; loss of birefringence, biostructure and grain boundaries; and micritisation.

A single subrounded probable geogenic calcite crystal of $1.1 \mathrm{~mm}$ diameter is present, but no other limestone evidence was noted.

Inorganic Poorly sorted mix of subrounded mica-schist, quartzite, dolerite, chlorite-schist $\leq 5 \mathrm{~mm}$, angular to non-calcareous subrounded monocrystalline quartz $\leq 1.1 \mathrm{~mm}$, with very low concentrations of plagioclase feldspar and clinopyroxene (diopside?) to $0.4 \mathrm{~mm}$.

Carbonaceous Low concentration of wood-charcoal inclusions including a 1.5 -mm-long ring porous grain.

Sween has yet been identified, although the identification of another shell-rich (C. edule and $O$. edulis shell included) lime mortar in a late secondary phase of masonry in the nearby chapel of Kilmory Knap (4 km SSE of Castle Sween; Thacker 2016) suggests wider chronologically-contingent processes are at work.
The large MERLF assemblage removed from Castle Sween was comprised entirely of wood-charcoal and contains a range of taxa consistent with surrounding woodland populations, including birch (Betula), hazel (Corylus), ash (Fraxinus), holly (Ilex) and oak (Quercus). This assemblage presents decreasing Quercus and increasing Betula and 
Table 2 Stone sample thin section descriptions

\section{Sample Thin section description}

code

CSA.11 Poorly sorted locally bimodal grain distribution to $0.75 \mathrm{~mm}$ (Fig. 9a)

Quartz - subangular to subrounded, often elongate, grading to $0.75 \mathrm{~mm} ; 60-65 \%$ Field of view.

Feldspar - plagioclase and microcline subrounded grading to $0.3 \mathrm{~mm} ; 2-5 \%$ Field of view.

Mica - degraded white mica grading to $0.2 \mathrm{~mm}$; locally high concentrations to $5 \%$ Field of view.

Rocks - quartz-rich subangular to subrounded rock fragments grading to $0.5 \mathrm{~mm} ; 10 \%$ Field of view.

Cement - high incidence of grain-supported textures and much cement has likely been lost through weathering. Grains commonly surrounded by clay_often apparently degraded mica.

Porosity-moderate; $15-20 \%$.

CSA.12 A polycrystalline clast dominated by highly birefringent calcite crystals with a lower concentration of non-carbonate quartz-rich lithologies (Fig. 9b). The texture is heterogeneous and foliated, including layers of more coarse inequidimensionally distributed calcite crystals grading up to $0.5 \mathrm{~mm}$, and layers of finer calcite crystals grading up to $0.1-0.15 \mathrm{~mm}$ only. All calcite crystals are oriented with a high concentration of triple-point junctions, and grain boundaries are irregular without any salient indentation.

The layering in this section is further emphasized locally high concentrations of quartzose materials which are generally oriented along the same axis.

Corylus fractions in successive phases, however, and this trend is continued by the 18 sample wood-charcoal assemblage removed from a sixteenth to mid-seventeenth century kiln during the castle excavations which was reportedly dominated by alder and birch with some hazel, ash and oak (Mills
1996, 552-553). The relative sizes of these assemblages are not unproblematic, but a chi-square test on the current data does suggest that phasing has a statistically significant effect on the evidence for oak/ash MERLF in the Castle Sween study $(T=25.9, T(5 \%)=6.0, \nu=2)$. That stands of fast growing Betula and Corylus often colonize ground where oak has been cleared provides an ecological mechanism for this trend, and the increase in these shorter-lived taxa is suggestive of fuel extraction from a more open woodland environment (Birks 1977, 121).

Correlating the building's archaeological evidence with local palaeoenvironmental evidence at Castle Sween and elsewhere across the region is also revealing. A recent study in the neighbouring lordship of Glassary presented a precise standalone date range for the construction of Castle Fincharn of 1245-1285 cal AD (68.2\% probability; Castle Fincharn Construction Completed; Thacker 2020, Fig. 6), and linked this event with a radiocarbon dated palynological study suggesting an increasingly open late medieval woodland was beginning to form around mid-upper Loch Awe from $1240 \mathrm{AD}$ (Thacker 2017; Sansum 2004). Indeed, within the c. 1240$1590 \mathrm{AD}$ zone associated with Lower Fernoch (19 km NE of Castle Fincharn; 8.2 km NNE of Innes Chonnell), arboreal pollen fell from 83 to $41 \%$ TLP (total land pollen), with a steady fall in Betula, Quercus and Alnus throughout this period (Sansum 2004, 209-221). Other palynological studies suggest the vegetational history of Knapdale developed quite differently, however, with a 'single major clearance event' around $1681 \pm 80 \mathrm{BP}$ reported in sediment from Lochan Taynish (7.4 km NNE of Castle Sween; marked LaT in Fig. 2) resulting in tree pollen falling to $60 \%$ TLP with particularly sharp falls in Quercus (Rymer 1974, 213), and a similarly 'dramatic period of deforestation beginning around $1300 \mathrm{BP}$

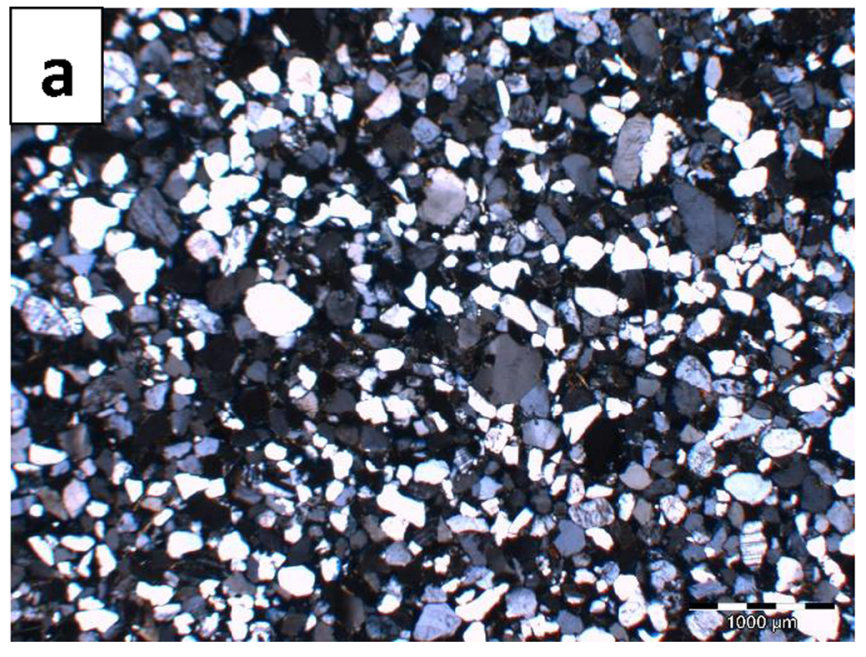

Fig. 9 a, b Photomicrographs of stone thin sections. a Photomicrograph of thin section CSA.11. Highlighting a poorly sorted grain distribution. XPL; $1.0 \mathrm{~mm}$ scale bar. b Photomicrograph of thin section CSA.12.

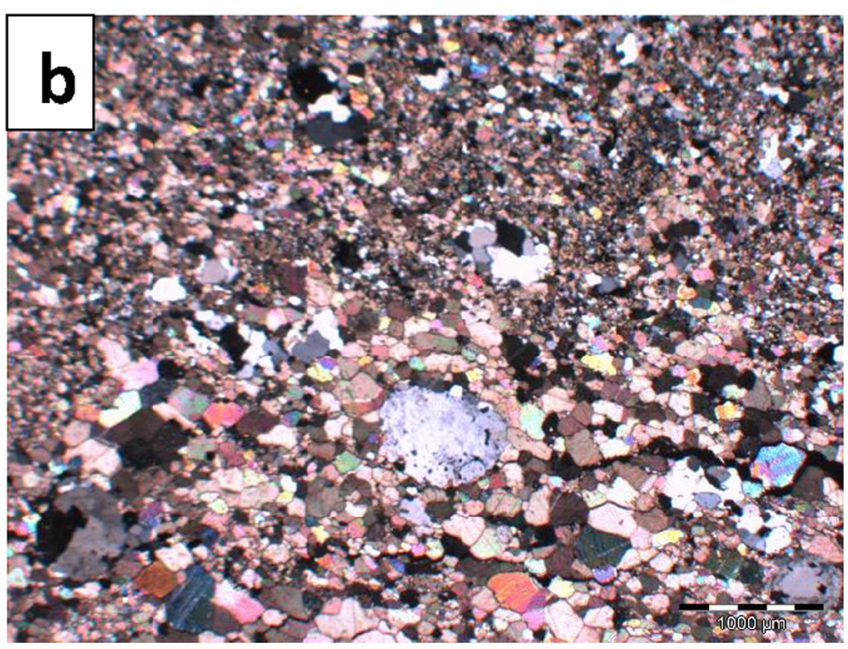

Highlighting foliated graded layers of highly birefringent calcite crystals and some evidence for quartzose intraclasts. XPL; $1.0 \mathrm{~mm}$ scale bar 


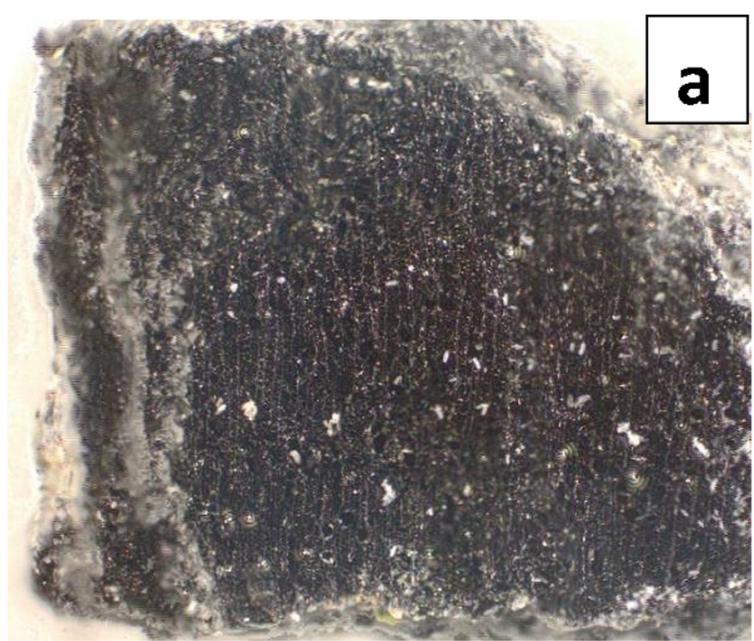

Fig. 10 a, b MERLF Photomicrographs. a Photomicrograph of MERLF fragment CSA.3d in transverse section. Highlighting a diffuse porous structure with abundant doubles, and no wide rays, characteristic of Betula sp. The transverse face of this fragment measures $2.5 \times 2 \mathrm{~mm}$. b

and continuing into the second millennium AD' at Loch Cill an Aonghais (Birks 1993; 18 km SSE of Castle Sween; marked as LCaA in Fig. 2). Indeed, these extreme changes in Knapdale's woodland cover appear more closely comparable to palynological evidence from the Oban area of Lorn (50 km NNE of Castle Sween), which suggested communities had 'comparatively little impact on the environment' before 'rapid and permanent deforestation' between 1100 and 900BP, which decreased tree and shrub populations by between two-thirds and a half (Macklin et al. 2000, 118). Significantly, therefore, whilst the Castle Fincharn study indicated this masonry building (and probably Innes Chonnell) was constructed near the beginning of distinctive late medieval changes in the vegetational history of mid-upper Loch Awe, the more dramatic deforestation events in Knapdale and Lorn substantially pre-date masonry construction at their administrative castle centres of Sween, Skipness and Dunstaffnage.

The chronological range of this data has further implications for our interpretations of causality, when compared with evidence for climate change. Proxy evidence for the MCA in western

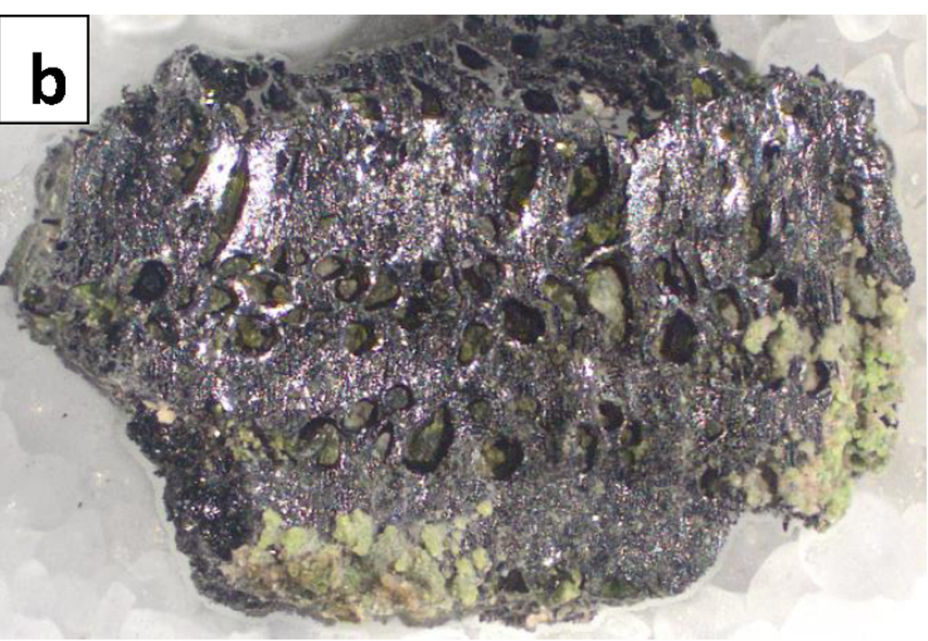

Photomicrograph of MERLF fragment CSA.2d in transverse section. Highlighting the ring porous biostructure with large spring vessels characteristic of Quercus sp. and 3+ years of growth. The transverse face of this fragment measures $3 \times 2 \mathrm{~mm}$

Scotland has been captured in a decadal scale radiocarbon dated study of benthic foraminiferal oxygen isotope records in Loch Sunart, with relatively low isotopic values (equating to higher temperatures) reported in a sub-interval dating to $\sim 916$ to 1030 AD (Cage and Austin 2010). That shorter periods of high isotopic values dating to 1046-1116 AD and 1543-1604 AD were also reported in this study is more unexpected, however, particularly since proxy data for shallow seawater temperatures (SST) in Loch Sween (generated at biweekly resolution from $\mathrm{Ca} / \mathrm{Mg}$ ratios in $L$. glaciale) very clearly demonstrates that Knapdale experienced climatic conditions similar to those reported elsewhere across Europe in the later medieval and early modern periods - including 'a distinct period of cooler temperatures between $\sim 1418$ and the late 1600s [which] coincides with the LIA that reached spatially distinct minima in the Northern hemisphere between 1400-1700' (Kamenos 2010, 22443; see for example Lamb 1977, fig. 17.2). Whilst the more gradual environmental changes around Loch Awe can be related to a complex suite of contemporary internal and external ecosystemic pressures including increasing late medieval climatic effects of the LIA, the deforestation of south Knapdale and Lorn appears to have taken place

Table 3 Summary archaeobotanical character of the MERLF assemblage from four constructional phases of Castle Sween. Be - Betula, Co - Corylus, Fr - Fraxinus, Il - Ilex, Qu - Quercus. 3n was not removed and so is not included in this table

\begin{tabular}{|c|c|c|c|c|c|c|c|c|c|c|c|c|c|}
\hline \multirow[t]{2}{*}{ Phase } & \multirow[t]{2}{*}{ Sample context } & \multirow[t]{2}{*}{ Assemblage size } & \multicolumn{6}{|c|}{ Sample taxonomy } & \multicolumn{5}{|c|}{ Sample curvature } \\
\hline & & & Be. & Co. & Fr. & Il. & Qu. & No I.D. & None & Low & Mod. & High & No I.D. \\
\hline 1 & Curtain Wall & 48 & 1 & 1 & 11 & - & 34 & 1 & 35 & 3 & 4 & 3 & 3 \\
\hline 3 & NW Tower & 19 & 6 & 1 & - & 1 & 10 & 1 & 10 & 3 & 5 & - & 1 \\
\hline 4 & NE Tower & 3 & 1 & 2 & - & - & - & - & 2 & - & - & 1 & - \\
\hline 5 & West Gate & 1 & - & - & - & - & - & 1 & - & - & - & - & 1 \\
\hline Total & & 71 & 8 & 4 & 11 & 1 & 44 & 3 & 47 & 6 & 9 & 4 & 5 \\
\hline
\end{tabular}




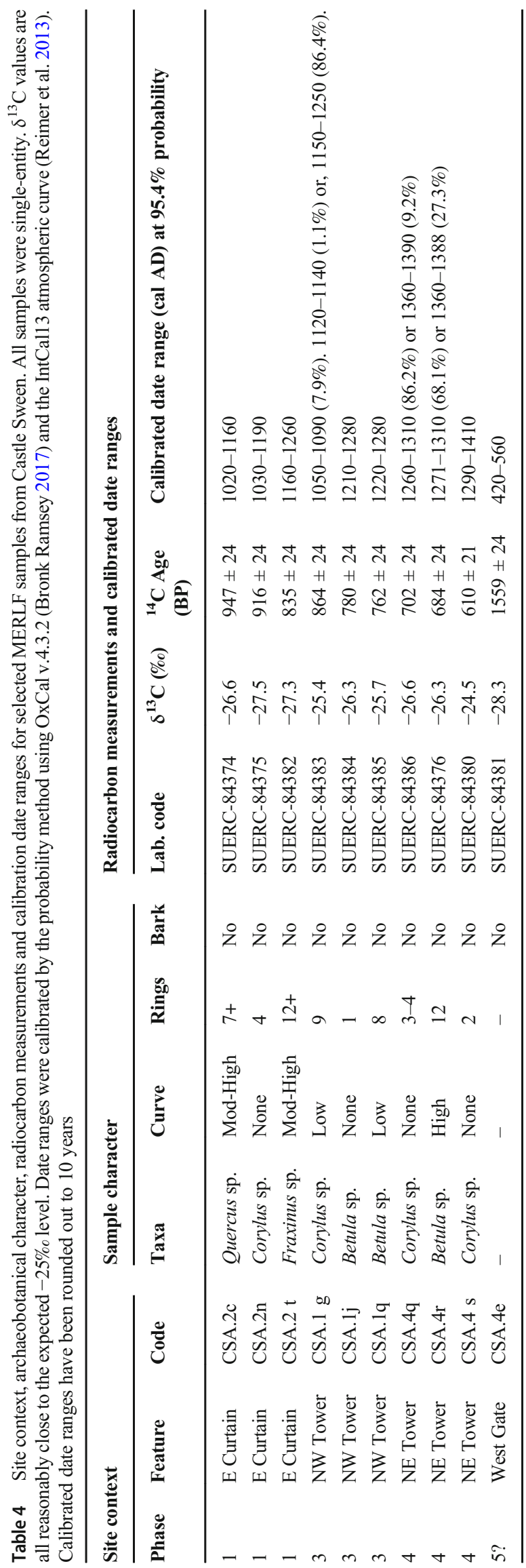

in the more climatically benign MCA and so are more clearly attributable to the management strategies of the local population. Moreover, all four of the castle buildings discussed above were constructed toward the very end of the MCA, suggesting they should be interpreted initially as geocultural products of the surrounding political and physical environment, rather than alien disruptors.

Overall, the evidence is beginning to suggest that the ecologically rich mosaic of environments surrounding Loch Sween throughout the post-medieval period were already in place when the primary phase enclosure at Castle Sween was constructed. The Quercus-rich character of the primary phase assemblage very clearly contrasts with the thirteenth century Corylus-dominated MERLF assemblage from nearby Castle Fincharn, however, and with the Betula-dominated MERLF assemblage recently examined from nearby Dunivaig Castle (Islay). Indeed, the MERLF assemblages from these three sites currently present a striking Corylus-Quercus-Betula transect across mid-Argyll to the Inner Hebrides although, until the Dunivaig assemblage is radiocarbon dated, the extent to which these contrasts are predicated on phytogeographic rather than biocultural factors is currently unknown. This chronological caveat is important as woodland populations are dynamic. Much more work is required before we can suggest this MERLF evidence is related to the late medieval decline in oak timber availability across Scotland more generally (Crone and Mills 2012), but the trend is broadly consistent with a seminal study of wood-charcoal from occupational contexts at Sandal Castle, West Yorkshire, which was dominated by oak in the twelfth/thirteenth century and became increasingly diverse over time (Bartley 1976, 233-4). It is certainly possible that the conversion of significant volumes of local oak for building timber-framed structures in the primary phase castle enclosure at Castle Sween increased availability of smaller Quercus stems for limekiln fuel in this earliest period of masonry construction, and this is also likely to have had a not insignificant effect on the character of the surrounding Loch Sween woodland.

The formality of the architecture at Castle Sween is paralleled by the character of its fabric. The oak/ash-fired limestone-lime mortar associated with Sween's primary phase

Fig. 11 Probability distributions of dates from Castle Sween standalone Bayesian model 1a, including phasing interpretations and radiocarbon data. Very early sample CSA.4e (SUERC-84381) has not been included in the model. Plotted in OxCal v4.3.2 (Bronk Ramsey 2017) and calibrated using IntCal13 atmospheric curve (Reimer et al. 2013), the remaining nine radiocarbon dates have been situated within three phases (depending on sample context) and tagged with outlier probabilities of between 5 and $100 \%$ (depending on botanical character) within separate 'General' and 'Charcoal' outlier models (Bronk Ramsey 2009b). The End Boundary distributions 'Castle Sween Construction Phase 1' to 'Castle Sween Construction Phase 4' are estimates of the date when each of these four structural phases was completed. The smaller brackets beneath each distribution represent the highest probability distributions at $68.2 \%$ and $95.4 \%$ probability 
OxCal v4.3.2 Bronk Ramsey (2017); r:1 IntCal13 atmospheric curve (Reimer et al 2013)

$\left[\begin{array}{c}\text { Sequence Castle Sween P } \\ \text { TaU_Boundary Castle Sw } \\ \text { Phase Castle Sween MER } \\ R_{-} \text {Date SUERC-84374 } \\ R_{-} \text {Date SUERC-84375 } \\ R \text { Date SUERC-84382 }\end{array}\right.$

Boundary Castle Sween Construction Phase-1

Sequence Castle Sween Phase 3

Tau_Boundary Castle Sween Woodland 3

Phase Castle Sween MERLF Assemblage 3

$R$ Date SUERC-84385

$R$ Date SUERC-84384

$R$ Date SUERC-84383

Boundary Castle Sween Construction Phase 3

Sequence Castle Sween Phase 4

Tau_Boundary Castle Sween Woodland 4

Phase Castle Sween MERLF Assemblage 4

$R$ Date SUERC-84376

$R$ Date SUERC-84380

$R$ Date SUERC-84386

Boundary Castle Sween Construction Phase 4

Sequence Castle Sween Stratigraphy 1

=Cast/e Sween Construction Phase 1

Castle Sween Construction Phase 2

=Castle Sween Construction Phase 3

Sequence Castle Sween Stratigraphy 2

=Castle Sween Construction Phase 1

=Castle Sween Construction Phase 2

=Cast/e Sween Construction Phase 4

Sequence Castle Sween Phasing Probability

=Castle Sween Construction Phase 3

=Castle Sween Construction Phase 4

$\begin{array}{llll}400 & 600 & 800 & 1000\end{array}$

Modelled date (AD) 
Table 5 Probability distributions from Castle Sween 'standalone' model 1a. All distributions have been rounded out to 5 years

\begin{tabular}{lllll}
\hline R-Date lab code & \multicolumn{2}{l}{ Unmodelled distributions (cal AD) } & \multicolumn{2}{l}{ Modelled distributions (cal AD) } \\
\hline Phase 1 & $68.2 \%$ probability & $95.4 \%$ probability & $68.2 \%$ probability & $95.4 \%$ probability \\
SUERC-84374 & $1030-1155$ & $1025-1155$ & $1080-1170$ & $1025-1205$ \\
SUERC-84375 & $1045-1160$ & $1030-1185$ & $1050-1165$ & $1035-1205$ \\
SUERC-84382 & $1165-1245$ & $1160-1260$ & $1165-1220$ & $1055-1265$ \\
Phase 3 & & & & \\
SUERC-84385 & $1245-1280$ & $1220-1280$ & $1245-1280$ & $1220-1280$ \\
SUERC-84384 & $1220-1270$ & $1215-1280$ & $1225-1270$ & $1215-1280$ \\
SUERC-84383 & $1160-1215$ & $1050-1245$ & $1165-1220$ & $1055-1260$ \\
Phase 4 & & & & \\
SUERC-84376 & $1275-1380$ & $1270-1390$ & $1275-1380$ & $1270-1390$ \\
SUERC-84380 & $1300-1395$ & $1295-1405$ & $1295-1395$ & $1290-1400$ \\
SUERC-84386 & $1270-1295$ & $1260-1385$ & $1270-1300$ & $1265-1385$ \\
End boundaries & & & & \\
Phase 1 & & & $1170-1250$ & $1070-1315$ \\
Phase 2 & & & $1210-1310$ & $1165-1410$ \\
Phase 3 & & & $1250-1380$ & $1225-1600$ \\
Phase 4 & & & $1295-1420$ & $1285-1590$ \\
Duration phases 1-4 & & $80-230$ years & $25-385$ years \\
\hline
\end{tabular}

enclosure is a hard, fine-textured, durable and bright white material, and the castle's curtain walls must have looked extraordinary when first constructed and coated with this luminescent material. The contrasting materials and techniques used in the construction of both phases of the NE Tower suggests the political and physical environment of the castle site had somehow changed by this fourteenth to fifteenth century period. The current model estimates that the first four phases of masonry construction at Castle Sween were completed over a period of 25 385 years (95.4\% probability), probably $80-230$ years $(68.2 \%$ probability; 'Duration First Four Main Phases'; Table 5), and suggests all four structures were completed before the climatic changes associated with the LIA began to significantly lower surface sea temperatures in the adjacent fjord. From this perspective, it is worthwhile considering how the character of these various changes in masonry fabric (rate, degree and type of change) might also evidence causality as the castle complex developed, with very sudden contrasts in technique or sources of (ostensibly permanent) geogenic materials perhaps indicating rapid changes in the socio-political environment, and more gradual trends in biogenic material compositions indicating subtler changes in the surrounding physical environment. In this regard, the gradual trend toward shorter-lived MERLF in the Castle Sween assemblage might indicate the latter constraint, whilst the masonry contrasts presented by the NE Tower also indicate the former.

Each of the building development, vegetational history and climate change models discussed above has been constructed from sedimentary studies predicated on materials analysis, stratigraphic interpretation and radiocarbon data. These models provide a chronologically constrained comparative framework from which more holistic multidisciplinary (archaeological, architectural, historical and ecological) interpretations of the built environment in various contexts can begin to emerge, allowing us to relate constructional events at Castle Sween to other buildings across the region and to changes in the surrounding climate and vegetation. Increased chronological precision and breadth in future work will be crucial to enabling a more meaningfully iterative relationship between these studies to develop at various different scales of enquiry. Whilst the $68.2 \%$ probability estimate generated for the NE Tower at Castle Sween suggests this structure was probably built after the NW Tower and before the LIA really took hold, for example, it is not yet possible to say how this constructional event relates to the mid-fourteenth century plague epidemic or shorter-
Table 6 Probability that the constructional estimate generated by model 1a for phase $3 \mathrm{NW}$ Tower precedes constructional estimate for phase 4

\begin{tabular}{lll}
\hline Probability $t_{1}<t_{2}$ & $t_{2}$ & \\
\cline { 2 - 3 } & Sween phase 3 completed & Sween phase 4 completed \\
\hline$t_{1}$ & & $\mathbf{0 . 7 1 9 4}$ \\
Sween phase 3 completed & 0 & 0 \\
Sween phase 4 completed & 0.28056 & \\
\hline
\end{tabular}


Table 7 Current summary of masonry and materials analysis at Castle Sween. Be - Betula, Co - Corylus, Fr - Fraxinus, Il - Ilex, Qu - Quercus

\begin{tabular}{|c|c|c|c|c|c|}
\hline Phase & Building feature & Masonry character & Mortar character & MERLF character & $\begin{array}{l}\text { Constructional } \\
\text { date estimate }\end{array}$ \\
\hline 1. & Curtain Walls & $\begin{array}{l}\text { Sandstone framing; well-sorted } \\
\text { rubble; formal masonry style. }\end{array}$ & $\begin{array}{l}\text { Moderate lime volume. High conc. } \\
\text { of fine, pure meta-limestone kiln } \\
\text { relicts. Bimodal temper mixture } \\
\text { dominated by sub-mm quartz. }\end{array}$ & $\begin{array}{l}\text { Qu. }(72 \%) F r .(23 \%) \\
\text { Il. - Be. }(2 \%) \text { Co. }(2 \%)\end{array}$ & $\begin{array}{l}\text { 1170-1250 cal AD } \\
\text { (68\% probability) } \\
1070-1315 \text { cal } A D \\
\text { (95\% probability) }\end{array}$ \\
\hline 2. & West Range & $\begin{array}{l}\text { Sandstone framing; narrow } \\
\text { walls; fine render coat. }\end{array}$ & $\begin{array}{l}\text { High lime volume. Very high conc. } \\
\text { of fine, pure meta-limestone kiln } \\
\text { relicts. Bimodal temper mixture } \\
\text { dominated by quartz to } 0.5 \mathrm{~mm} \text {. }\end{array}$ & & $\begin{array}{l}1210-1310 \text { cal } A D \\
\text { (68\% probability) } \\
1165-1410 \text { cal } A D \\
\text { (95\% probability) }\end{array}$ \\
\hline 3 & NW Tumble & $\begin{array}{l}\text { Sandstone framing; complex } \\
\text { setting out; composite } \\
\text { building. }\end{array}$ & $\begin{array}{l}\text { Low lime volume. Mod- low conc. } \\
\text { of meta-limestone kiln relicts of } \\
\text { variable purity. High conc. poorly } \\
\text { sorted quartz-rich temper mixture. }\end{array}$ & $\begin{array}{l}\text { Qu. }(55 \%) \text { Fr. - Il. }(6 \%) \text { Be. } \\
\quad(33 \%) \\
\text { Co. }(6 \%)\end{array}$ & $\begin{array}{l}\text { 1250-1380 cal } A D \\
\text { (68\% probability) } \\
1225-1600 \text { cal } A D \\
\text { (95\% probability) }\end{array}$ \\
\hline 4 & NE Tower & $\begin{array}{l}\text { Schist, quartzite and sandstone } \\
\text { framing; stone re-use; poorly } \\
\text { sorted informal rubble. }\end{array}$ & $\begin{array}{l}\text { Voided low lime volume. Low conc. } \\
\text { of meta-limestone kiln relicts with } \\
\text { abundant quartz intraclasts. High } \\
\text { conc. coarse poorly sorted temper } \\
\text { mixture. }\end{array}$ & $\begin{array}{l}\text { Qu. - Fr. - Il. - Be. (33\%) Co. } \\
\qquad(67 \%)\end{array}$ & $\begin{array}{l}\text { 1295-1420 cal AD } \\
\text { (68\% probability) } \\
1285-1590 \text { cal } A D \\
\text { (95\% probability) }\end{array}$ \\
\hline 5 & West Gate & $\begin{array}{l}\text { Rubble or no framing; small } \\
\text { rubble stone; informal } \\
\text { masonry style. }\end{array}$ & $\begin{array}{l}\text { High volume of lime. High conc. } \\
\text { marine shell fragments. Poorly } \\
\text { sorted temper mixture in mod-low } \\
\text { conc. }\end{array}$ & & \\
\hline
\end{tabular}

term fluctuations in climate. The secondary modifications undertaken to this building are also culturally significant, and yet the date of this event is not currently associated with any independent chronological evidence and remains speculative. Given the potential to extend the biweekly proxy climate data from neighbouring Loch Sween back to 4500 cal BP (N. Kamenos pers. comm.), further archaeological analysis of the upstanding building should aim to fully populate and increase precision in the summary table presented in the conclusion above (Table 7).

By investigating the materials used to construct Castle Sween in various periods, the above study has highlighted the ecological diversity which has emerged in Knapdale as various communities have sought to manage the peninsula's resources - a task which from the late twelfth century was embodied in the masonry castle building itself. Indeed, the multiphase character of the castle complex suggests these cultural practices had very successfully sustained a population, and no doubt a surplus, throughout. The medieval history of the west Highlands and Islands may be dominated by massive changes in the political geography of the wider region, as the Norwegian, Scottish and English Crowns sought power over those same resources, but chronologically and geographically constrained multidisciplinary studies are vitally important for our understanding of how the environment was being continually re-negotiated in response to complex political and physical processes.

Acknowledgements The SMCCCP is funded by the University of Stirling and Historic Environment Scotland (Archaeology Programme, Cultural Resources Team and Radiocarbon Call-off Contract). Scheduled Monument Consent relating to the material sampling was administered by Historic Environment Scotland, with input from Jamie MacPherson, Richard Strachan and Mary MacLeod (all HES). Mike Hall (University of Edinburgh) prepared all thick and thin sections, archaeobotanical identification was supervised and verified by Mike Cressey (CFA Archaeology), and radiocarbon analysis was undertaken by the Scottish Universities Environmental Research Centre (SUERC). Nick Kamenos discussed the Loch Sween palaeoclimatic evidence and Geoff Allan donated calcareous stone sample CSA.12. Neil Fraser (HES) advised on image copyright and Penny Pendreigh (Kilmartin Museum) kindly forwarded chapters 9 and 10 of Leslie Rymer's PhD thesis. Richard Oram (University of Stirling) commented on an early draft and the comments of two anonymous reviewers improved the structure of the paper significantly.

Open Access This article is licensed under a Creative Commons Attribution 4.0 International License, which permits use, sharing, adaptation, distribution and reproduction in any medium or format, as long as you give appropriate credit to the original author(s) and the source, provide a link to the Creative Commons licence, and indicate if changes were made. The images or other third party material in this article are included in the article's Creative Commons licence, unless indicated otherwise in a credit line to the material. If material is not included in the article's Creative Commons licence and your intended use is not permitted by statutory regulation or exceeds the permitted use, you will need to obtain permission directly from the copyright holder. To view a copy of this licence, visit http://creativecommons.org/licenses/by/4.0/.

\section{References}

Adair J (1703) Description of the sea coast and islands of Scotland. Can be viewed at https://maps.nls.uk/coasts/chart/1031

Bain J (1884) Calendar of documents relating to Scotland AD 12721307. HM General Register House, Edinburgh 
Bartley D (1976) Palaeobotanical evidence. In: Sawyer P (ed) medieval settlement: continuity and change. pp. 226-235

Birks H (1977) The Flandrian forest history of Scotland: a preliminary synthesis. In: Shotton F (ed) British quaternary studies: recent advances. Oxford University Press, Oxford, pp 119-135

Birks H (1993) Loch Cill an Aonghais. In: Gordon J, Sutherland G (eds) The quaternary of Scotland 6. Chapman \& Hall, London

Blaeu J (1654a) Knapdalia Provincia que sub Argathelia censetur, [vel], The Province of Knapdail which is accounted a member of Argyll. Auch Tumoth, Pont https://maps.nls.uk/view/00000424

Blaeu J (1654b) Iura Insula, The Yle of Iura one of the westerne Iles of Scotland. https://maps.nls.uk/view/00000479

Bøggild O (1930) The shell structure of the molluscs. D. Kgl. Danske Vidensk. Selsk. Skr. (Naturvidensk og Mathem.) 9(2):231-326

Bronk Ramsey C (2009a) Bayesian analysis of radiocarbon dates. Radiocarbon 51(1):337-360

Bronk Ramsey C (2009b) Dealing with outliers and offsets in radiocarbon dating. Radiocarbon 51(3):1023-1045

Bronk Ramsey C (2017) Methods for summarizing radiocarbon datasets. Radiocarbon 59(2):1809-1833

Brown M (2004) The wars of Scotland 1214-1371. Edinburgh University Press, Edinburgh

Cage A, Austin W (2010) Marine climate variability during the last millennium: the loch Sunart record, Scotland, UK. Quaternery Science Reviews 29:1633-1647

Crone A, Mills C (2012) Timber in Scottish buildings, 1450-1800: a dendrochronological perspective. Proc Soc Antiqu Scotl 142:329 369

Dunbar J, Duncan A (1971) Tarbert Castle: a contribution to the history of Argyll. The Scottish Historical Review 50(149, part 1):1-17

Dunbar E, Cook G, Naysmith P, Tripney B, Xu S (2016) AMS ${ }^{14}$ C dating at the Scottish universities environmental research Centre (SUERC) radiocarbon dating laboratory. Radiocarbon 58(1):9-23

Duncan A, Brown A (1957) Argyll and the isles in the earlier middle ages. Proc Soc Antiqu Scotl 90:192-220

Elsen J (2006) Microscopy of historic mortars - a review. Cement \& Concrete Research 36:1416-1424

Everett P, Gillespie M, Tracey E (2015) Provenance of building stones in four 'galley castles' in Argyll. Minerals \& Waste Programme Commissioned Report OR/15/053. British Geological Survey, Edinburgh

Ewart G, Triscott J (1996) Archaeological excavations at Castle Sween, Knapdale, Argyll \& Bute, 1989-90. Proc Soc Antiqu Scotl 126:517557

Fagan B (2000) The little ice age. How climate made history 1300-1850. Basic books, New York

Fraser W (1880) The red book of Menteith, 2 volumes

Graham A, Collingwood R (1923) Skipness Castle. Proc Soc Antiqu Scotl 57:266-287

Holmes N (1996) Coins. In Ewart \& Triscott, archaeological excavations at castle Sween, Knapdale, Argyll \& Bute, 1989-90. Proc Soc Antiqu Scotl 126:553-554

Hughes J, Cuthbert S (2000) The petrography and microstructure of medieval lime mortars from the west of Scotland: implications for the formulation of repair and replacement mortars. Materials \& Structures 33:594-600

Innes C (1854) Origines Parochiales Scotiae. The antiquities ecclesiastical and territorial of the parishes of Scotland. Volume 2 part 1. W. H. Lizars, Edinburgh

Kamenos N (2010) North Atlantic summers have warmed more than winters since 1353, and the response of marine zooplankton. Proc Natl Acad Sci U S A 107(52):22442-22447

Lamb H (1977) Climate: past, present and future. Volume 2 climatic history and the future. Routledge, New York

Leslie A, Hughes J (2004) High-temperature slag formation in historic Scottish mortars: evidence for production dynamics in 18th-19th century lime production from Charlestown. Mater Charact 53: 181-186

MacGibbon D, Ross R (1889) The Castellated \& Domestic Architecture of Scotland from the twelfth to the eighteenth century. 3:58-63

Macklin M, Bonsall C, Davies F, Robinson M (2000) Humanenvironment interactions during the Holocene: new data and interpretations from the Oban area, Argyll, Scotland. The Holocene 10(1):109-121

Maitland Thomson J (1912) The register of the great seal of Scotland Vol 1 AD. HM General Register House, Edinburgh, pp 1306-1424

McVean D (1964) Woodland and scrub. In: Burnett J (ed) The vegetation of Scotland. Oliver \& Boyd, London, pp 144-167

Mercator, G. (1595). Scotia Regnum. https://maps.nls.uk/scotland/rec/ 130 Accessed

Mills C (1996) Charcoal. In: Ewart G, Triscott J. Archaeological excavations at Castle Sween, Knapdale, Argyll \& Bute, 1989-90. Proceedings of the Society of Antiquaries of Scotland 126: 552-3

Mitchell H (1935) The microscopic structure of the shell and ligament of cardium (cerastoderma) corbis martyn. J Morphol 58(1):211-220

Munro J, Munro R (1986) Acts of the lords of the isles. Scottish History Society, Edinburgh

Oram R, Adderley P (2008) Lordship and environmental change in Central Highland Scotland c.1300-c.1400. Journal of the North Atlantic 1(1):74-84

Ordnance Survey (1873) Six-inch 1st Edition 1843-1882 . Argyllshire, Sheet CLXXIX (includes north Knapdale; south Knapdale). Survey Date 1869. https://maps.nls.uk/view/74427461 Accessed 06-082018

Pont T (1583-1614) Cowell. pp 83-84. https://maps.nls.uk/pont/texts/ transcripts/ponttext83v-84r.html Accessed 29/08/2018

Ratcliffe D (1977) A nature conservation review. The selection of biological sites of national importance to nature conservation in Britain. 2 volumes. Cambridge University Press, Cambridge

Ratcliffe D, McVean D (1962) Plant communities in the Scottish highlands. HMSO, London

RCAHMS (1971) Royal Commission on the Ancient and Historical Monuments of Scotland. An inventory of the monuments in Argyll, vol. 1: Kintyre. RCAHMS, Edinburgh

RCAHMS (1992) Royal Commission on the Ancient and Historical Monuments of Scotland. An inventory of the monuments in Argyll, vol. 7: Mid-Argyll \& Cowal. RCAHMS, Edinburgh

Reimer P, Bard E, Bayliss A, Beck J, Blackwell P, Bronk Ramsey C, Grootes P, Guilderson T, Haflidason H, Hajdas I, Hattž C, Heaton T, Hoffmann D, Hogg A, Hughen K, Kaiser K, Kromer B, Manning S, Niu M, Reimer R, Richards D, Scott E, Southon J, Staff R, Turney C, van der Plicht J (2013) IntCal13 and Marine13 radiocarbon age calibration curves 0-50,000 years cal BP. Radiocarbon 55(4):1869 1887

Roberts J (1977) The Dalradian Rocks of Knapdale and North Kintyre. Scott J Geol 13:113-124

Roy W (1747-55). Military survey of Scotland

Rymer L (1974) The Palaeoecology and Historical Ecology of the Parish of North Knapdale, Argyllshire. Unpublished PhD thesis, University of Cambridge

Sansum P (2004) Historical resource use and ecological change in seminatural woodland: western oakwoods in Argyll, Scotland. Unpublished $\mathrm{PhD}$ Thesis. University of Stirling

Schweingruber F (1990) Microscopic wood anatomy. Structural variability of stems and twigs in recent and subfossil woods from Central Europe. Swiss Federal Institute for Forest, Snow and Landscape Research, Davos

Sellar W (1971) Family origins in Cowal and Knapdale. Scottish Studies $15: 21-31$

Simpson W (1967) Castle Sween. TGAS new series 15:3-14

Stephenson D, Gould D (1995) British Regional Geology: the Grampian Highlands, 4th edn. HMSO for the BGS, London 
Thacker M (2016) Constructing Lordship in North Atlantic Europe: the archaeology of masonry mortars in the medieval and later buildings of the Scottish North Atlantic. 3 Vols. Unpublished PhD. thesis, University of Edinburgh

Thacker M (2017) MacGillechrist's castle: an environmental study in medieval buildings archaeology from Argyll. In: Martin P (ed) Castles and galleys. A re-assessment of the historic galley-castles of the Norse-Gaelic seaways. IBT, Laxay, pp 157-171

Thacker M (2020) Dating medieval masonry buildings by radiocarbon analysis of mortar-entrapped relict limekiln fuels - a buildings archaeology. Journal of Archaeological Method \& Theory 27:381438

Thacker M, Hughes J, Odling N (2019) Animal, vegetable or mineral? Characterising shell-lime, maerl-lime and limestone-lime mortar evidence from the Late Norse and medieval site of Tuquoy, Orkney. In, J Álvarez, J Fernández, Í Navarro, a Durán \& R Sirera, editors,
Proceedings of the $5^{\text {th }}$ Historic Mortars Conference. RILEM PRO 130: Paris. pp. 758-777

Tipping R (1994) The form and fate of Scotland's woodlands. Proc Soc Antiqu Scotl 124:1-54

University of St Andrews. (2007-20). RPS: Records of the Parliaments of Scotland to 1707. John Balliol, Second Roll of Parliament. www. rps.ac.uk Accessed 21-01-2020

Walker F (2000) Argyll and Bute. The buildings of Scotland series. Penguin, London

Ward G, Wilson S (1978) Procedures for comparing and combining radiocarbon age determinations: a critique. Archaeometry 20:19-32

White T (1875) Archaeological sketches in Scotland. District of Kintyre, William Blackwood \& Sons, Edinburgh \& London

Publisher's note Springer Nature remains neutral with regard to jurisdictional claims in published maps and institutional affiliations. 